OPEN ACCESS

Edited by:

Viji Sarojini,

The University of Auckland,

New Zealand

Reviewed by:

Carmen Cuadrado,

Instituto Nacional de Investigación y

Tecnología Agroalimentaria

(INIA), Spain

Shalini Gaur Rudra,

Indian Agricultural Research Institute

(ICAR), India

*Correspondence:

Caleb Acquah

cacquah@uottawa.ca

Specialty section

This article was submitted to

Sustainable Food Processing,

a section of the journal

Frontiers in Sustainable Food Systems

Received: 17 March 2021

Accepted: 26 April 2021

Published: 21 May 2021

Citation:

Acquah C, Ohemeng-Boahen $G$

Power KA and Tosh SM (2021) The

Effect of Processing on Bioactive Compounds and Nutritional Qualities

of Pulses in Meeting the Sustainable

Development Goal 2

Front. Sustain. Food Syst. 5:681662.

doi: 10.3389/fsufs.2021.681662

\section{The Effect of Processing on Bioactive Compounds and Nutritional Qualities of Pulses in Meeting the Sustainable Development Goal 2}

\author{
Caleb Acquah ${ }^{1 *}$, Godfred Ohemeng-Boahen ${ }^{2}$, Krista A. Power ${ }^{1}$ and Susan M. Tosh ${ }^{1}$ \\ ${ }^{1}$ School of Nutrition Sciences, Faculty of Health Sciences, University of Ottawa, Ottawa, ON, Canada, ${ }^{2}$ Department of \\ Chemical Engineering, Kwame Nkrumah University of Science and Technology, Kumasi, Ghana
}

Diversification of plant-based food sources is necessary to improve global food and nutritional security. Pulses have enormous nutritional and health benefits in preventing malnutrition and chronic diseases while contributing positively to reducing environmental footprint. Pulses are rich in diverse nutritional and non-nutritional constituents which can be classified as bioactive compounds due to their biological effect. These bioactive compounds include but are not limited to proteins, dietary fibres, resistant starch, polyphenols, saponins, lectins, phytic acids, and enzyme inhibitors. While these compounds are of importance in ensuring food and nutritional security, some of the bioactive constituents have ambivalent properties. These properties include having antioxidant, anti-hypertensive and prebiotic effects. Others have a deleterious effect of decreasing the digestibility and/or bioavailability of essential nutrients and are therefore termed antinutritional factors/compounds. Various processing techniques exist to reduce the content of antinutritional factors found in pulses. Traditional processing of pulses comprises soaking, dehulling, milling, germination, fermentation, and boiling, while examples of emerging processing techniques include microwaving, extrusion, and micronization. These processing techniques can be tailored to purpose and pulse type to achieve desired results. Herein, the nutritional qualities and properties of bioactive compounds found in pulses in meeting the sustainable development goals are presented. It also discusses the effect of processing techniques on the nutritional and non-nutritional constituents in pulses as well as the health and environmental benefits of pulse-diet consumption. Major challenges linked to pulses that could limit their potential of being ideal crops in meeting the sustainable development goal 2 agenda are highlighted.

Keywords: pulses, food security, nutritional quality, processing, health benefits, environmental benefits, sustainability

\section{INTRODUCTION}

Maintaining and/or enhancing the nutritional quality of food to combat malnutrition and ensuring food security is always an important issue of interest to researchers, consumers, and policymakers. One of the ways to achieve the sustainable development agenda (goal 2: zero hunger, food security, eliminating malnutrition, and sustainable agriculture) by 2030 is to encourage the consumption 
and processing of pulses as consumer food products (Ferreira et al., 2021). Pulses are dry edible seeds of plants in the family of legumes (Fabaceae or Leguminosae). Numerous varieties of pulses exist globally, as recognised by FAO, and they include lentils, dry beans (navy beans, pinto beans, and kidney beans), broad beans (field beans and horse beans), field peas (yellow peas and green peas), lupins, chickpeas, bambara beans, pigeon peas, vetches, cowpeas, pulses nes (Mudryj et al., 2014; Ferreira et al., 2021). Among these, dry beans, chickpeas, dry/field peas, cowpeas, lentils, and broad beans were the most commonly grown produced pulse crops around the world. In 2019, global production of these pulse crops were as follows: 28.9, 14.25, $14.18,8.90,5.73$, and 5.43 MT, respectively (Food and Agriculture Organisation (FAO), 2021a).

Pulses are ideal crops as they form an essential part of a modern agri-food system due to their enormous benefits in what is now so-called "pulse magic." They have a high content of proteins, fibres, polyphenols, and micronutrients such as irons, zinc, and vitamins (Tosh et al., 2013; Brummer et al., 2015; Shi et al., 2017). They can be grown in drier areas due to the low water footprint, have high economic value, and contribute to food and nutritional security. Pulse crops can also fix atmospheric nitrogen in the soil through their root nodules to reduce the use of fertilisers. The degree of nitrogen fixation from pulses is estimated as follows: faba beans (90\%), field peas (80\%), lentils (80\%), chickpeas (70\%), and dry beans (50\%) (Saskatchewan, 2021). When used in rotation with other crops, pulses provide residual nitrogen and improve the microbial population and diversity of soils (Saskatchewan, 2021).

Pulses have been a vital component of the human diet for ages (Leterme, 2002). In 2018, about 92.4 million tonnes of pulses were grown globally, representing an increase of about 63\% from 1998 (Ben-Belhassen and Rawal, 2021). However, the global consumption of pulses remains low, especially, in western countries, where there is less familiarity with cooking them and less knowledge regarding their nutritional and health benefits (Robinson et al., 2019). Raw pulses for food processing come in various forms including whole seeds, split, dehulled, and flour. They can be processed into diverse food products such as beverages, soups, pasta, meat alternatives, baked goods, and canned pulses (Bhat et al., 2013; Argel et al., 2020; Saget et al., 2020). Consumption of pulses has many health benefits including prevention of cancer, lowering glycemic index, and protection against cardiovascular diseases (Ha et al., 2014; Ferreira et al., 2021). That aside, pulses such as faba beans, lupins, and field peas have relevance in the preparation of nutrient rich animal feed (Robinson et al., 2019; Parisi et al., 2020). Besides their food and feed applications, there are emerging applications for the use of pulse bioactives such as bioactive proteins, dietary fibre, resistant starch, polyphenols, and oligosaccharides extracted from pulses for nutraceuticals, functional foods, drug delivery, edible bioplastics, and biofuel production (Okagu et al., 2018; Acquah et al., 2020b; Tassoni et al., 2020).

Nonetheless, the nutritional value and health benefits of pulses may be less than optimal due to the use of inappropriate processing methods, the presence of antinutritional factors, and poor metabolic performance from consumers which could be due to conditions such as dysbiosis (Hernandez-Aguirre et al., 2020; Szczebyło et al., 2020). Better accessibility of nutrients can be achieved by processing pulses to inactivate bioactive compounds which can act as antinutritional factors (Granito et al., 2005; Hemalatha et al., 2007; Cardador-Martínez et al., 2012; Liu Y. et al., 2020). Bioactive compounds that act as antinutritional compounds in pulses chiefly include phytic acid, enzyme inhibitors, lectins, and polyphenols (Mbithi et al., 2001; Luo and Xie, 2013). Also, vicine and convicine are antinutritional compounds that can be specifically found in faba beans (Rizzello et al., 2016). Generally, pulses are cooked before being consumed by humans. Cooked pulses have a strong beany flavour which is usually unpleasant to consumers. The beany flavour in pulses emanates from the enzymatic activities of lipoxygenase and alcohol oxidoreductase (Baysal and Demirdöven, 2007; Jiang et al., 2016; Ma et al., 2016). Lipoxygenase catalyzes the oxidation of fatty acids (such as linoleic and linolenic acids) to form hydroperoxides (Baysal and Demirdöven, 2007). Hydroperoxides further react to form volatile and non-volatile off-flavour compounds in oxidation reactions induced by thermal or chemical treatments or catalysed by endogenous enzymes such as peroxygenase (Jiang et al., 2016; Ma et al., 2016). These endogenous enzymes can be inactivated when effectively processed to increase consumer acceptance. This review aims to discuss the nutritional attributes and health benefits of raw and processed pulses in ensuring global food and nutritional security. It also highlights the contribution of pulses in achieving a modern sustainable agricultural process with health benefits.

\section{IMPROVING FOOD AND NUTRITIONAL SECURITY}

According to the 2019 revision of the "United Nations Population Estimates and Projections," the world population is expected to increase to 8.5 billion in 2030, 9.7 billion in 2050, and 11.2 billion by 2100 (United Nations (UN), 2021). An imminent challenge facing the world is the ability to resource the everincreasing population with healthy diets from a sustainable agrifood system. On that note, "The 2030 Agenda for Sustainable Development" goal was accepted by all UN member states in 2015 with one of the key goals (Goal 2) centred on sustainable food production to end hunger (United Nations (UN), 2015). According to the EAT-Lancet Commission on Healthy Diets from Sustainable Food Systems, more than 820 million people in the world currently lack adequate access to food with many more consuming low-quality diets resulting in undernutrition, micronutrient deficiencies, and heightening of diet-related diseases (Willett et al., 2019). Furthermore, the report concluded that there needs to be a decline in the global consumption of unhealthy foods including red meat and sugar by at least $50 \%$. On the contrary, there needs to be an increase in the intake of fruits, vegetables, nuts, and legumes by twice the current amount by 2050 to achieve healthy diet standards (Willett et al., 2019).

Importantly, malnutrition is a condition endemic globally due to the intake of diets which do not provide the necessary 
quantity or balance of nutrients. It may come in three forms; (i) undernutrition, (ii) micronutrient deficiencies, and (iii) obesity and diet-related non-communicable diseases (World Health Organisation (WHO), 2020). According to a World Health Organisation report in 2020, malnutrition accounts for about $45 \%$ of mortalities in children under the age of 5 and is predominant in poor and developing countries. In addition, $\sim 462$ million adults are diagnosed to be underweight with about 1.9 billion having a body mass index $\geq 25$, that is, they are either overweight or obese. In 2015, the global food protein demand was estimated at 202 million tonnes and is expected to increase to about 360-1,250 million tonnes by 2050 (Acquah et al., 2020a). The continuous growth in the world population, increasing levels of affluence, sociodemographic changes, urbanisation, and climate changes adversely impact the ability to meet current protein demands heightening the impact of malnutrition (Acquah et al., 2020a).

Notably, animal protein sources increase the carbon footprint in food production relative to plant proteins. A study conducted using the E3IOT environmentally extended input output database in Europe showed that healthier diets may have lower environmental impacts (Tukker et al., 2011). It is estimated that global agricultural and food consumption contributed about $25 \%$ of greenhouse gas emissions, with animal-based foods (particularly meat and dairy) contributing more than $50 \%$ of the total impact (Tukker et al., 2011; Tilman and Clark, 2014). Aside from their adverse environmental impacts, high consumption of red and processed meat is linked with chronic diseases and high mortality (Schwingshackl et al., 2017; Zheng et al., 2019). There is therefore a need to shift-toward high protein plant foods, which is a more sustainable and healthier source of protein.

Pulse crops, by virtue of being rich in proteins, dietary fibre, and micronutrients as well as having a nitrogen fixationability and having a low carbon footprint, are essential in achieving the sustainable development food goals set by the United Nations Food and Agriculture Organisation. However, there are challenges such as the strong "beany" flavour of pulses. Also, the global yield of pulses, $929 \mathrm{~kg} / \mathrm{ha}$, is very low and at about $25 \%$ of the total yield of cereals (Rawal and Navarro, 2019). There is therefore a need to diversify plant-based food sources in ensuring global food and nutritional security. There are also few pulse breeding studies and investments when compared to cereal and animal breeding.

Marinangeli et al. (2017) carried out a comprehensive review of 20 varieties of pulses, which included dry peas, lentils, chickpeas, and dry beans, to define a recommended dietary pulse serving size for adults. It was revealed that at present there is no universally accepted dietary guideline for pulse consumption as this is influenced by multiple factors such as the variation in dietary cultures, the dietary needs of a particular population, and infrastructure of food systems across countries and regions. Out of about 95 countries reported to have a dietary guideline by the FAO (Food and Agriculture Organisation (FAO), 2021b), pulses were included in the dietary guidelines of 16 of those countries (Marinangeli et al., 2017). On that note, the estimated average mass equivalents obtained for one-half cup $(125 \mathrm{~mL})$ of cooked pulses was $104.6 \pm 22.8 \mathrm{~g}$. Therefore, it was recommended that a minimum intake of $100 \mathrm{~g}$ of cooked pulses per day, or on days pulses are consumed, would provide the needed amount of macro- and micronutrients to the diet to address nutritional issues such as protein malnutrition, potassium intake, and iron, folate, and zinc insufficiency (Marinangeli et al., 2017).

\section{Genetic Breeding}

Genomic tools in crop breeding are useful for the study and development of agronomic traits of interest for the speciation and domestication of plants (Blair et al., 2007; Mba, 2013). For example, the significance of induced genetic mutations in crop breeding includes high throughput, safety, low cost, and a coherent method to generate inheritable outcomes in seeds (Mba, 2013). A typical setback in the commercial utilisation of pulses is their low yield and lack of variabilities for positive inheritable traits. For instance, cowpeas are self-pollinated crops resulting in the limited genetic base necessary to set crossbreeding programs that can yield improved features. To circumvent this challenge, Raina et al. (2020) used a systematic induced mutant breeding approach to generate mutant genotypes. This resulted in new, non-GMO cowpea seed cultivars with improved yielding capacity, resilience to environmental stress, and the expression of new polymorphic protein bands.

Also, pulses such as mung bean, cowpea, and pigeon pea are susceptible to parasitic invasion by insects resulting in crop failure (Bawa et al., 2017; Sodedji et al., 2020). With pulses such as cowpea and pigeon pea being some of the most consumed crops in developing countries (Merga and Haji, 2019; Majili et al., 2020), the impact of such invasions results in severe damage to food availability and quality of nutrition in very deprived areas. This can be controlled through the use of pesticides and the development of transgenic pulses with inheritable traits resistant to pest invasion (Sodedji et al., 2020). An induced genetic mutation has also been utilised in studies to produce nutritious pulses by lowering the amount of antinutritional compounds such as phytic acids and tannins while increasing the bioavailability of macronutrients and minerals (Blair et al., 2007). Lowering the ratio of phytic acids to mineral acid content through induced genetic mutation increases the content of freely available mineral acids. It is important therefore to emphasise that precaution should be taken in the manner in which such pulses are processed in a meal as there could be excessive leaching of minerals during soaking and cooking relative to conventional pulses, which could be counterproductive (Hummel et al., 2020).

Another area in pulses in which genetic studies are becoming essential is in minimising the effect of seed coat postharvest darkening in dry beans, such as common beans, pinto beans and cranberry beans, faced by producers and consumers (Elsadr et al., 2011). This is due to the accumulation and ensuing oxidation of proanthocyanidin in their seed coat. Bassett et al. (2002) showed that the $J$ gene was the genetic locus initiating the postharvest darkening in common beans while those with the recessive allele jj had no problems of postharvest darkening. On this note, Erfatpour and Pauls (2020) developed an R2R3-MYB gene-based marker obtained from "Wit-rood boontje" to aid bean breeders in the selection of non-darkening dry beans carrying the recessive jj genes in early generations as opposed to waiting to screen the 
phenotypic segregation. R2R3-MYB genes are known to regulate biosynthesis of proanthocyanidin (Erfatpour and Pauls, 2020).

\section{BIOACTIVE COMPOUNDS}

Bioactive compounds in food are molecules that have a biological effect (adverse and/or potential health benefits) on the body beyond basic nutrition. Both nutrients and antinutritional factors found in pulses can have positive bioactive properties. For instance, bioactive peptides from pulse proteins may have properties such as antioxidant, antihypertensive, and anticancer effects, polyphenols have been demonstrated to have antioxidant effects, while oligosaccharides and polysaccharides produce short chain fatty acids which elicit numerous physiological benefits including promoting intestinal health.

Antinutritional factors are bioactive compounds that are produced as secondary metabolites in plants as part of their defence mechanism against predators, competitor plants, and stressful environmental conditions (Singh et al., 2003; AbdelAal, 2016). However, these secondary metabolites tend to disrupt the bioavailability and utilisation of nutrients and minerals either on their own or via their metabolic products in humans and monogastric animals (Samtiya et al., 2020). This results in nutrient and mineral deficiency in consumers. Also, some antinutritional factors can be toxic (Habtamu Fekadu and Ratta, 2014). In the appropriate quantity, chemical structure, interactions with other food components, and metabolic performance of a consumer, these antinutritional factors could also have some bioactive properties with health benefits (Champ, 2002; Muzquiz et al., 2012). They are therefore preferably termed as "non-nutrients" by some nutritionists and food scientists. The ambivalent properties of common food bioactives are presented in Table 1. Antinutritional factors can be classified as either proteins or non-protein compounds based on their structure (Martín-Cabrejas et al., 2009). Notably, the proteinaceous antinutritional factors are resistant to endogenous digestive enzymes and the acidic $\mathrm{pH}$ in the stomach (Muzquiz et al., 2012; Bessada et al., 2019). They include lectins, enzyme inhibitors, and antifungal peptides, whereas non-protein antinutritional factors include alkaloids, phytic acid, tannins, and saponins (MartínCabrejas et al., 2009; Muzquiz et al., 2012; Bessada et al., 2019).

\section{Dietary Fibre}

The American Association of Cereal Chemists International (AACCI) defines dietary fibre as "the edible part of plants or analogous carbohydrates that resist digestion and absorption processes in the small intestine with partial or complete fermentation in the large intestine. Dietary fibre includes polysaccharides, oligosaccharides, lignin, and associated plant substances. Dietary fibres promote beneficial physiological effects including laxation, and/or blood cholesterol attenuation, and/or blood glucose attenuation" (American Association of Cereal Chemists (AACCFC), 2001). The polysaccharide components comprises of different macromolecules including cellulose and other $\beta$-glucans, hemicelluloses, resistant starch, pectins, mucilages, and gums in plants (Singh et al., 2017).
Dietary fibres can be classified as either soluble or insoluble fibre; both having various health benefits. For instance, soluble fibre slows the rate of absorption and increases excretion of lipids, bile acids and cholesterol in the human body resulting in an improvement in cardiovascular health and modulation of glycemic levels in the blood. Additionally, soluble fibre promotes intestinal health through fermentation and the production of short chain fatty acids. On the other hand, insoluble fibre enhances bowel motility, the growth of intestinal microflora and promotes gastrointestinal health (Tosh and Yada, 2010; Dahl et al., 2012). For those not habituated to consuming pulses, fermentation of oligosaccharides commonly found in pulses, raffinose, stachyose and verbascose, can lead to excess gas production and discomfort. However, the gut microbiota can quickly adapt to the presence of these oligosaccharides in the diet encouraging the growth of beneficial short chain fatty acids producing bacteria (Veenstra et al., 2010). Additionally, dietary fibres positively influence satiety in humans.

Generally, the dietary fibre content of pulses (either raw or cooked) is in the range of $13-35 \mathrm{~g}$ per $100 \mathrm{~g}$ of edible portion with the insoluble fibre constituting about $76-83 \%$ of the total fibre content (Rawal and Navarro, 2019). More so, the dietary fibre composition of pulses differs with species, cultivars, the type of processing method, and processing conditions applied (Tosh and Yada, 2010; Singh et al., 2017). Conspicuously, a vast number of physicochemical and functional properties such as water-binding capacity, bulk density, viscosity, gelling properties, and fermentability of pulse flours and ingredients are influenced by the fibre content and characteristics (Malcolmson and Han, 2019).

The Institute of Medicine recommends a dietary fibre intake of $20-38 \mathrm{~g}$ per day from food for adults ( $>18$ years) and $14 \mathrm{~g} / 1,000 \mathrm{kcal}$ for all age groups (Abdullah et al., 2015b). Nonetheless, the average dietary fibre consumption currently falls short in most countries. For instance, the reported average intake for adult male and females, respectively, for some countries are as follows: Canada, 19.1 and $15.6 \mathrm{~g}$ per day (Abdullah et al., 2015a); United States of America, 19.6 and $15.9 \mathrm{~g}$ per day; Austria, 20 and $20 \mathrm{~g}$ per day; Germany, 25 and $23 \mathrm{~g}$ per day; Italy, 19.6 and 17.7; Japan, 18.8 and $18.0 \mathrm{~g}$ per day; UK, 14.7 and 12.8 (Stephen et al., 2017); and 20-25 g per day in Australia (Better Health Care (BHC), 2021). Due to the widespread low consumption of dietary fibre, it is recommended to increase the valorisation of pulse products which are simple to use or consume such as canned pulses and pulse snacks. Using cooked pulses, the dietary fibre requirement per day can be obtained by consuming about 100$200 \mathrm{~g}$ per day. It must be noted that a pulse-based product can be claimed to be a source of fibre when it is processed to have a fibre content $\geq 3 \mathrm{~g}$ per $100 \mathrm{~g}$ or a minimum of $1.5 \mathrm{~g}$ of fibre per $100 \mathrm{kcal}$ (418 kJ) (Stephen et al., 2017).

\section{Proteins, Peptides, and Amino Acids}

Generally, pulses contain about $17-40 \%$ of protein on a dry weight basis with high amounts of the essential amino acid lysine and low amounts of sulphur-containing amino acids cysteine, tryptophan, and methionine (Dahl et al., 2012; Malcolmson and Han, 2019). Globulins and albumins are the major proteins by 
TABLE 1 | Possible benefits and/or adverse effects of some bioactive compounds present in pulses.

\begin{tabular}{|c|c|}
\hline $\begin{array}{l}\text { Bioactive } \\
\text { compounds }\end{array}$ & Description \\
\hline Alkaloids & $\begin{array}{l}\text { Naturally occurring amines } \\
\text { critical in the self-defence } \\
\text { mechanism of pulses }\end{array}$ \\
\hline Oligosaccharides & $\begin{array}{l}\text { Major oligosaccharides in pulse } \\
\text { are } \alpha \text {-galactosides and are } \\
\text { primarily made of raffinose, } \\
\text { stachyose, and verbascose }\end{array}$ \\
\hline Polyphenolics & $\begin{array}{l}\text { The key group of secondary } \\
\text { plant metabolites found in food } \\
\text { They differ in chemical structure } \\
\text { from the simple molecules (such } \\
\text { as phenolic acids) to the highly } \\
\text { polymerised molecules (such as } \\
\text { proanthocyanidins) }\end{array}$ \\
\hline
\end{tabular}

Saponins

Are bitter taste triterpene glycosides which form stable foams in aqueous solutions

Phytosterols

Gammaaminobutyric acid (GABA)

Lectins

\begin{abstract}
Phytic acid
\end{abstract}
Oxalic acid

Vicine and convicine

Tannins

Trypsin and chemotrypsin inhibitors

Also known as myo-inosito hexakisphosphate. It is the primary storage form of phosphorus in seeds Also known as oxalates. They are metabolic end products

They are pyrimidine glycosides and can degrade at higher

They are a group of high molecular weight polyphenols susceptible to heat.
Have antioxidant, antibacterial, antitumor, and anti-inflammatory activities

Ease bowel movement, minimise the levels of $\mathrm{N}$-nitroso compounds (known to be potentially carcinogenic) in the gut, have a prebiotic effect which lactobacilli and bifidobacterial while minimising enterobacteria population in the colon anti-hypertensive, anti-atherosclerotic anti-thrombotic, anti-allergic, anti-bacterial, and anti-cancer properties. alpha-amylase inhibition slows glucose absorption.

Reduce the absorption of dietary lipids, cholesterol, and bile acids

Effective in lowering the levels of blood cholesterol, intestinal absorption of dietary and endogenous cholesterol.

Reduce blood pressure in hypertensive patients, anticancer properties, and modulation of blood cholesterol levels

Have antioxidant and anti-tumour properties, slows down digestion and absorption of carbohydrates, and modulates glycaemic levels in the blood.

Has anticarcinogenic properties and antioxidant activity existing in the genus Vicia. They lack stability in an acidic medium temperatures.

They are secondary metabolites

No health benefits

Preliminary evidence indicates prevention of cardiac arrhythmia, growth of malaria parasites, antitumor and anti-inflammatory properties of vicine, convicine, and divicine.

Have antioxidant activities

Have anti-cancer properties
Benefits/Implication enhances the population of

Have antioxidant,
Adverse effects

Can cause digestive, reproductive and immunological disorders as well as affecting the central nervous system

Generates methane when fermented in the lower gut resulting in abdominal pain and flatulence in those lacking bacteria which convert oligosaccharides to short chain fatty acids.

Decrease the bioavailability of some minerals, protein digestibility, and absorption of bioactive peptides

Can bind to the cells of the small intestine which minimises the absorption and utilisation of nutrients.

There is evidence of potential risk of cardiovascular diseases emanating from the formation of sterol oxidation products from phytosterols during food processing

High concentrations of GABA could result in hypersomnia

Decrease the bioavailability of polysaccharides and minerals. Can also cause blood clotting, bloating, and stomach upset.

Inhibits absorption of trace minerals such as calcium, copper, iron, zinc magnesium, and manganese.

Inhibits the absorption of minerals and can also cause kidney stones when consumed in high amounts
Causes acute hemolytic anaemia known as favism
Reference(s)

Kurek, 2019

Tosh and Yada, 2010; Veenstra et al., 2010; Singh et al., 2017

Karaś et al., 2017; Sun et al., 2020

Margier et al., 2018; Bessada et al., 2019

Alemany et al., 2014; Singh et al., 2017

Ngo and Vo, 2019

Pusztai and Grant, 1998; Liu Z. et al., 2013

Gupta et al., 2015; Shi et al., 2018

Shi et al., 2018

Abdalla Hussein, 2012; Cardador-Martínez et al., 2012

Decrease energy and protein

Margier et al., 2018 digestibility, as well as interrupting with iron and zinc absorption

Complexates proteins resulting in lower protein digestibility and sulphur-amino acid quantities.
Avilés-Gaxiola et al., 2018 
proportion in pulses whereas prolamins and glutelins are minor components. The storage proteins in pulses are mainly made up of the $7 \mathrm{~S}$ and/or $11 \mathrm{~S}$ globulins and $2 \mathrm{~S}$ albumins. The major storage proteins in peas and faba beans are the $7 \mathrm{~S}$ and $11 \mathrm{~S}$ globulins whereas for cowpea, French beans, kidney beans, and mung beans are 7S globulins (Kimura et al., 2008; Yin et al., 2011). Though uncommon, the storage proteins in pulses are recognised as food allergens. This includes the $11 \mathrm{~S}$ globulin proteins ( 23 and $35-40 \mathrm{kDa}$ ), 2S albumin (10 and $12 \mathrm{kDa}$ ) in chickpea (Takács et al., 2014), 7S globulin proteins $(47 \mathrm{kDa})$ in lentil (Sackesen et al., 2020), and $7 \mathrm{~S}$ globulins (36 and $44 \mathrm{kDa}$ ), $11 \mathrm{~S}$ globulins $(63 \mathrm{kDa})$ in pea proteins (Sanchez-Monge et al., 2004). That notwithstanding, the potential allergenic effect of storage proteins is minimised significantly through efficient treatment processes which increases the in vivo digestibility of proteins into bioactive peptides and amino acids, as well as reducing their IgE-binding ability (Shriver and Yang, 2011).

Embedded in dietary proteins are bioactive peptides which can be generated using endogenous enzymes in the body or exogenous enzymes such as papain and alcalase. These bioactive peptides have been shown to have significant health benefits to the body and can be used for the development of functional foods (Udenigwe and Aluko, 2012; Gnasegaran et al., 2017). The amino acid distribution of pulses varies with type, processing method, and processing conditions. Notably, chickpea is rich in the amino acids leucine, isoleucine, and arginine; lentils, phenylalanine and serine; cowpea, methionine and threonine; and faba beans, arginine and leucine (Rahate et al., 2021). Pulses, when compared to most plants, tend to have higher nutritional security scores due to their high protein content, protein quality scores, slowly digestible starch content and high dietary fibre content in pulses. For instance, the protein content in pulses (examples are: peas, beans, lentils, and chickpeas, 22-26\%; faba beans, $27-34 \%$; and lupins, $33-47 \%$ ) is about twice the quantity present in cereals (wheat, 9-15\%; barley, 7-13\%; and rice, 2-5\%) and with better protein quality scores (Malcolmson and Han, 2019).

\section{TRADITIONAL AND EMERGING PROCESSING EFFECTS ON PULSE NUTRITIONAL QUALITY}

Before cooking, pulses can be processed through soaking, dehulling, germination, milling and fermentation. It must be noted that dehulling has minimal effect in reducing or eliminating antinutritive factors, with the exception of decreasing phenolic compound content, since such bioactive compounds are mostly located in the cotyledon (Shi et al., 2018). Cooking, which is also another form of processing pulse seeds, occurs in different ways such as but not limited to traditional pan boiling, microwave heating, grilling, infrared heating, and extrusion (Marconi et al., 2000). The aforementioned food processing techniques help to inactivate microorganisms and improve or maintain the nutritional quality, shelf-life, flavour, and texture of food (Krishnamurthy et al., 2008; Chandrasekaran et al., 2013). Milling pulses into flours increases the exposed surface area and breaks the cell walls within the seeds, which reduces the required cooking time and increases nutrient availability. It increases the potential to incorporate pulse ingredients into processed foods, like bread, pasta, falafel, bhaji and pakoras. However, it also exposes cell contents to enzyme activity which may result in increased beany flavour unless the flour is treated to inactivate enzymes. Also, the processing of pulses into products enhances the valorisation of "consumer rejectable" seeds into end products which can be sold as food/feed to minimise food wastage while transferring the nutritional attributes and beneficial bioactive compounds to consumers (Luo and Koksel, 2020; Portman et al., 2020).

Pulse processing techniques can be used in isolation or in combination to achieve such desired results. Parameters used during pulse processing must be tailored-to-purpose for each type of pulse to yield the right nutritional profile in products for consumers. For instance, whereas weaning foods are processed to have highly digestible contents to meet growth demands, snacks for adults living with obesity are recommended to have high slowly-digestible contents to reduce nutrient absorption (Asif et al., 2013). As such, this section discusses various traditional and emerging techniques used in the processing of pulses to enhance nutritional security.

\section{Soaking}

Soaking is generally a primary part of pulse processing to soften the seeds and reduce the cooking time. However, lentils and peas can be cooked without prior soaking. During the process of soaking, the content of small molecules such as phytate, tannins, trypsin inhibitor, oligosaccharides, saponins, and polyphenolic compounds in pulses can be significantly lowered to minimise potential adverse effects (Siddhuraju and Becker, 2005; Khattab and Arntfield, 2009; Martín-Cabrejas et al., 2009). As a result, the bioavailability of proteins and micronutrients is enhanced, but antioxidant and prebiotic potential may be lowered. Processing conditions to consider during soaking include duration, type of media/solution, temperature, and $\mathrm{pH}$ (Siddhuraju and Becker, 2005; Khattab and Arntfield, 2009; Martín-Cabrejas et al., 2009; Ertaş and Türker, 2014). The common media for the soaking of pulses is tap water at room temperature. The effectiveness of soaking in reducing antinutritional compounds varies with pulse seeds, the soaking conditions, and the chemical structure of the antinutritional compounds. In a study conducted by MartínCabrejas et al. (2009), it was observed that whereas phytic acid content was reduced by $38 \%$ in lentils and $33 \%$ in Castellano chickpea there was no significant change in white, pink-mottled cream beans and Sinaloa chickpea. Studies showing a decrease in phytic acid during soaking is as a result of the activation of the endogenous phytase and the diffusion of its product into the soaking medium (Khattab and Arntfield, 2009; Martín-Cabrejas et al., 2009). Ertaş and Türker (2014) also showed a decrease in phytic acid content in chickpea from 47.39 to $55.71 \%$ after increasing the soaking time from 2 to $12 \mathrm{~h}$, and from 50.80 to $51.46 \%$ after increasing the $\mathrm{pH}$ of the soaking media from 4 to 8. In addition, the different media $\mathrm{pH}$ and duration of soaking had varied improvement in in vitro protein digestibility (IVPD), mineral availability, and total phenolic content (Ertaş and Türker, 2014). Oligosaccharide content can be reduced by up to $75 \%$ by 
soaking pulses overnight and discarding the soak water (Han and Baik, 2006).

\section{Germination}

Seed germination is an inexpensive and conventional bioprocessing technique common in food processing. Germination in pulses occurs when the dry seeds absorb moisture and break dormancy until the embryonic axis elongates (Xu et al., 2020). The break of dormancy is associated with the synthesis of phenolics and other bioactive compounds which elicits protective responses (Mbithi et al., 2001; Xu et al., 2020). Germination reduces antinutritional factors and the strong beany taste of pulses. There is also an improvement in protein and starch digestibility, amino acid content, bioavailability of trace minerals, total dietary fibres, and soluble sugars (Wu et al., 2012; Xu et al., 2018). Critical parameters essential for seed germination to take place are temperature, water, oxygen, and light (Rifna et al., 2019). Notably, the efficacy of a germination process is reliant on the type of pulse seed and processing conditions such as presence or absence of light, the quantity of water being added, and duration of germination (López-Amorós et al., 2006; Ma et al., 2018; Setia et al., 2019; Xu et al., 2019).

The effect of germination on pulses has shown some promising reports on bioactive compounds and functionality. López-Amorós et al. (2006) carried out a semi-pilot scale study to investigate the effect of germination on three pulse seeds, beans (Phaseolus vulgaris L. variety La Granja), peas (Pisum sativum L., variety Elsa), and lentils (Lens culinaris L., var. Castellana), under different conditions. Biochemical analysis showed that before germination, there was a significant decrease in total phenolic compounds, carbohydrates, and phytates in all three pulse seeds during the period of soaking. After germination, changes in the profile of phenolic compounds and antioxidant activity were observed and were influenced by the type of pulse seeds and processing conditions. The optimum germination conditions deduced from their study for the pulse seeds were predicated on the half-maximal inhibitory concentration $\left(\mathrm{IC}_{50}\right)$ for antioxidant activity and were as follows: beans, 6 days of germination in the dark and peas, 4 days of germination in the presence of light. However, there was a negative effect of germination on lentils based on the antioxidant activity tested. Wu et al. (2012) also observed a 100-fold increase in the content of isoflavone (due to heightened levels of formononetin and biochanin A) and a wide range of diversity in isoflavanoids (25 isoflavanoids: 20 isoflavones, 2 isoflavanones, and 3 pterocarpan phytoalexins) to demonstrate the significant effect of germination on bioactive compounds in chickpeas (Cicer arietinum L., Turkey). Germination of the chickpeas was carried out in the dark for 4 days after $24 \mathrm{~h}$ of soaking at room temperature (Wu et al., 2012). Similarly, germination of Bambara bean (Vigna subterranean) flours at 24,48 , and $72 \mathrm{~h}$ duration caused a decline of bioactive compounds such as phytic acid, tannin, and trypsin inhibitor. This resulted in the improvement of protein content (from 26.1 to $28.79 \mathrm{~g} / 100 \mathrm{~g}$ ), insoluble dietary fibre components (from 10.41 to $11.45 \mathrm{~g} / 100 \mathrm{~g}$ ), total dietary fibre (from 13.29 to $15.03 \mathrm{~g} / 100 \mathrm{~g}$ ), and total phenolic content (from 1.15 to $2.03 \mu \mathrm{molTE} / \mathrm{g}$ ). There was also improvement in trace minerals (calcium, magnesium, potassium), most of the amino acids, digestible starch, and in vitro protein digestibility (Chinma et al., 2021). Goyoaga et al. (2008) studied the effect of germination on the content of pyrimidine glucosides vicine and convicine, as well as non-proteic amino acid levo-3,4-dihydroxy-phenylalanine (LDOPA) in two varieties of faba beans, namely, Vicia faba L. vars. Alameda and Brocal. It was observed that germination decreased the content of vicine and convicine in the cotyledon with no change in L-DOPA content whereas in the embryo axis there was a decline in the content of vicine and an increase in the content of convicine. However, L-DOPA was found to significantly appear only in the embryo with the highest content detected after 6 days of germination. This phenomenon was observed in both varieties of faba beans. L-DOPA in faba beans has been reported to be effective in the treatment of Parkinson, hypertension, renal failure and liver cirrhosis diseases (Goyoaga et al., 2008).

\section{Fermentation}

Fermentation, which is also a conventional technique in food bioprocessing, is the chemical breakdown of a material using microorganisms. Fermentation activates endogenous enzymatic activity leading to hydrolytic reactions which cause a reduction in antinutritional factors, improvement in palatability and nutritional attributes of pulses. It also enhances the bioavailability of trace minerals through the formation of soluble organic acid complexes with the minerals. This phenomenon also prevents the development of any insoluble complexes between the minerals and phytate (Hemalatha et al., 2007). The key parameters to consider for optimal fermentation of pulses are microbial culture, enzyme activity, method of fermentation (solid state fermentation or liquid state fermentation), and environmental condition (Maleki and Razavi, 2020).

Natural fermentation was shown to result in partial or complete removal of $\alpha$-Galactosides (raffinose family of oligosaccharides), tannins, phytic acid, lectin and trypsin inhibitor activity in pulses (Cuadrado et al., 2002; Granito et al., 2005). In faba beans, the amount of vicine and convicine was significantly reduced by $>91 \%$ and condensed tannins in the protein fractions by $>40 \%$ after fermentation with Lactobacillus plantarum (Coda et al., 2015; Rizzello et al., 2016). Additionally, fermentation of faba beans improved the content of essential amino acids, $\gamma$-aminobutyric acid (GABA), total phenolic compounds, and in vitro protein digestibility (Coda et al., 2015).

The use of probiotic microorganisms in the fermentation of milk and curds has gained popularity with lots of demonstrated health benefits. However, the translation of this concept to pulses in the development of functional foods is limited and still burgeoning. To achieve superior results in bioactive compounds and nutritional qualities, germination of pulses can be combined with fermentation under optimised conditions (Simsek et al., 2014; Lee et al., 2018; Ma et al., 2018; Maleki and Razavi, 2020). $\mathrm{Ma}$ et al. (2018) carried out varied bioprocessing studies on soaked yellow peas. It was observed that germination, followed by fermentation drastically reduced the starch content of yellow peas by $11.2-11.7 \%$. Fermentation was done with the use of a mixed lactic acid bacteria culture (S. thermophiles, L. bulgaricus, and Lactobacillus acidophilus). The significant decrease in starch 
content. is due to the high amylolytic activity of Lactobacillus acidophilus in starch hydrolysis (Lee et al., 2001). Consequently, there was an improvement in protein content for both fermented yellow peas and germinated-cum-fermented yellow peas ( $\mathrm{Ma}$ et al., 2018). Significant reduction in tannin content and trypsin inhibitor activity due to degradation from endogenous enzymes and lactic acid bacteria enzymes. Furthermore, there was an improvement in in vitro protein digestibility and starch hydrolysis for germinated, fermented, and germinated-cumfermented yellow peas (Ma et al., 2018). The observed increase in in vitro protein digestibility and starch hydrolysis is due to the structural alteration of storage proteins, starch granules, and reduction of antinutritional factors activated by endogenous enzymes and lactic acid bacteria.

\section{Thermal Treatments}

Thermal treatment in this discussion includes boiling (traditional cooking), pressure cooking, roasting, hydrothermal cooking, and slow cooking. Boiling is the most common thermal processing approach to cook pulses before consumption (Xu and Chang, 2008). Thermal treatment of pulses inactivates or removes heatlabile antinutritional factors such as tannins, enzyme inhibitors and phenolics to enhance the nutritional value of pulses (Kalogeropoulos et al., 2010; Yeo and Shahidi, 2017). Although lectins and phytates are thermally stable, their activity can be lowered after heat treatments at high temperatures, $\geq 95^{\circ} \mathrm{C}$ (Pusztai and Grant, 1998; Gupta et al., 2015; Shi et al., 2018). Additionally, vicine and convicine present in faba beans were reduced by about 6.06 and $22.53 \%$ after being roasted, and 18.86 and $22.53 \%$ after being boiled, respectively (CardadorMartínez et al., 2012). Thermal treatments of pulses can result in structural changes such as protein denaturation as well as starch gelatinisation and retrogradation. This phenomenon consequently influences the functionality and applications of the treated pulse. Some key parameters to consider during thermal treatments of pulses comprise the method of cooking or heat application, type of pulse, cooking duration, and heating solution (such as water, salt, sugar) (Liu Y. et al., 2020).

Pulses respond differently to the removal of antinutritional factors when subjected to heat treatments (Kalogeropoulos et al., 2010; Shi et al., 2018). Kalogeropoulos et al. (2010) studied the effect of pan boiling on bioactive compounds in broad beans, chickpeas, yellow split peas, green split peas, lentils (small and large), pinto beans, black-eyed beans, white lupines, and five white bean varieties (small, medium, large, giant, elephant), in the form in which they are commonly consumed, in a Mediterranean diet. Therein, it was observed that the phytochemical content in the boiled pulses decreased in the pattern: lentils $>$ chickpeas $>$ pinto beans >lupines $>$ white beans varieties, broad beans, and split peas. Similarly, faba beans and lentils were noted to have better phenolic antioxidant activities than green peas after heat treatment in a study conducted by Liu Y. et al. (2020). This presupposes a similar trend in functionality is derived when consumed. Thus, further in vivo studies are necessary to elucidate the functional effect of eating different boiled pulses. Canning of pulses involves cooking at elevated pressures and higher temperatures than boiling in an open pot, which results in increased hydration of the seeds (Fabbri et al., 2016) and higher levels of resistant starch (Güzel and Sayar, 2012). The short preparation time makes them very convenient compared to dried pulses.

\section{Extrusion Cooking}

Extrusion cooking is a thermo-mechanical approach used in the processing of foods. The process involves high temperature, pressure, mechanical shear, and moisture within a short time interval in a tube resulting in molecular transformation into a unique plasticised food material (Qi et al., 2020). The benefits of extrusion cooking of pulses include starch gelatinisation, enhanced soluble dietary fibre content, maintenance of natural food colours and flavours. More so, there has been reported a reduction in lectin, tannins, phytic acids, enzyme inhibitors (trypsin, chemotrypsin, and $\alpha$-amylase inhibitors), and lipid oxidation (Alonso et al., 1998; Singh et al., 2007). Extrusion cooking provides an avenue for a continuous multi-operational unit which is energy efficient and has a high-quality output relative to other thermal/hydrothermal treatment processes (Adeleye et al., 2020).

Extrusion cooking has been used in the processing of pulses into ready-to-eat foods, confectionery products, precooked weaning meals, dry pet foods, etc. In the quest to valorise food waste generated during bread production, Luo and Koksel (2020) blended yellow pea flour and bread crumbs followed with low moisture extrusion cooking. The extrudate generated had high water binding capacity and water solubility indicating the degradation of starch during extrusion cooking. Qi et al. (2020) observed increasing extruding temperatures from 50 to $90^{\circ} \mathrm{C}$ resulted in improved in vitro starch digestibility and in vitro protein digestibility of pea flour. On the contrary, there was a decline in slowly digestible starch (SDS) content from $22.70 \%$ at $50^{\circ} \mathrm{C}$ to $16.02 \%$ at $90^{\circ} \mathrm{C}$. A high content of slowly digestible starch in diets is crucial in the slow release of glucose into the blood and prevention of obesity (Brummer et al., 2015). Notably, high extrusion temperatures could lead to Maillard reactions (nonenzymatic browning) involving free amino groups of protein and carbonyl groups of reducing sugars (Saldanha do Carmo et al., 2019). This results in the reduction of bioavailable amino acids and poor protein digestibility. The occurrence of Maillard reaction during pulse extrusion cooking is of concern when the processed pulse is to be used for weaning or as the only item in a specialised diet or feed. Nevertheless, Maillard reactions produce a typical brownish colour, crispiness, and sensory qualities which is usually desirable by consumers of ready-to-eat snacks (Wani and Kumar, 2016). The parameters for extrusion should be optimised depending on the pulse type and product to decrease the content of antinutritional factors while delivering the necessary nutritional values to the targeted consumer.

\section{Microwave Heating}

Microwave heating is a relatively new food processing technique and has a plethora of domestic and commercial applications including drying, cooking, thawing, pasteurisation, and preservation (Chizoba Ekezie et al., 2017). Microwaves are electromagnetic waves with operating frequencies between 
300 and $300 \mathrm{GHz}$. It is worth noting that domestic microwave devices typically operate at a frequency of $2.45 \mathrm{GHz}$ whereas industrial microwave systems operate at frequencies of $915 \mathrm{MHz}$ and $2.45 \mathrm{GHz}$ (Chandrasekaran et al., 2013). Key operating parameters for microwave heating technology are power level and exposure time. The benefits of microwave heating include high heating rates, a drastic decrease in cooking time, safe handling, ease of operation, and low maintenance (Dalmoro et al., 2018). Nevertheless, during microwave heating, there could be an uneven distribution of temperature due to the geometry of food, volume, and heat distribution (Vadivambal and Jayas, 2010). Compared to conventional heating techniques, microwave heating has a lesser effect on degrading the nutritional attributes of pulse foods due to the shorter cooking time (Marconi et al., 2000).

Pulses can be pre-treated for pest disinfestation and reduction in lipase activity, which causes strong beany flavour, using microwave technology prior to cooking (Jiang et al., 2016; Dalmoro et al., 2018). For effective use of microwave irradiation to pre-treat pulses, Dalmoro et al. (2018) assayed the dielectric properties of milled pulses viz beans (Phaseolus vulgaris L., variety Bingo), chickpeas (Cicer arietinum L., variety Cicerale), and lentils (Lens esculenta, variety Colliano) to arrive at a diameter of $11 \mathrm{~cm}$ and a thickness of $4 \mathrm{~cm}$. This ensured uniform penetrative volumetric heating. By so doing, the content of tannins and polyphenols were also significantly reduced in all three pulses during pre-treatment to increase the bioavailability of dietary proteins and minerals. Microwave technology has been used for the cooking of pulses which also reduced the antinutritional compounds (tannin, enzyme inhibitors) while increasing total starch, in vitro protein and starch digestibility (Ma et al., 2017). Microwave cooking of common bean and chickpea improved rapidly digestible starch (RDS) content by 53 and $36 \%$, while lowering slowly digestible starch (SDS) content by 30 and 28\%, respectively (Marconi et al., 2000). Hefnawy (2011) also showed a reduction in antinutritional compounds in lentils after being cooked with a microwave. Lentils were placed in tap water $(1: 10 \mathrm{w} / \mathrm{v})$ followed by cooking on a high-power level for $15 \mathrm{~min}$. Consequently, galacto-oligosaccharides and reducing sugars were significantly reduced in the drained lentils. Trypsin inhibitor activity, tannin, and phytic acid content were also reduced by $93.29,34.38$, and $39.17 \%$, respectively, illustrating the effectiveness of microwave cooking on pulses.

\section{Infrared Heating}

Infrared heating, also known as micronization, is an emerging technology being used in food processing with limited applications in pulse processing (Ogundele and Kayitesi, 2019). It is based on the use of electromagnetic radiation with frequencies operating between the visible $(0.38-0.78 \mu \mathrm{m})$ and microwaves $(1-1,000 \mathrm{~mm})$. More so, infrareds can be classified into 3 regions depending on the spectra ranges, that is, near-infrared $(0.75-1.4 \mu \mathrm{m})$, mid-infrared $(1.4-3 \mu \mathrm{m})$, and far-infrared $(3-1,000 \mu \mathrm{m})$. Infrared heating appliances for food processing typically operate with frequencies between 1.8 and $3.4 \mu \mathrm{m}$ (Fasina et al., 2001). The use of infrared heating has many benefits over conventional heating under similar conditions. This includes efficient heating with temperatures between 750 and $930^{\circ} \mathrm{C}$, shorter cooking time, more homogenous heating, lower energy cost, and minimal loss in food quality (Rastogi, 2012; Ogundele and Kayitesi, 2019). However, infrared heating has low penetration power and could cause swelling and fracture in pulses when subjected to longer heating times (Krishnamurthy et al., 2008). For bulk food products, it is recommended to use infrared heating in combination with techniques such as dehulling and microwave heating to ensure penetration of heat into the food (Krishnamurthy et al., 2008). The efficacy of infrared heating is reliant on parameters such as heating duration, surface temperature, moisture content, and geometry of pulse seeds or products (Ogundele and Kayitesi, 2019).

Infrared heating technology has been used in varied food processing applications such as dehydration, dry blanching, disinfestation, and inactivation of endogenous enzymes (Galindo et al., 2005; Sharma et al., 2005; Jeevitha et al., 2013). To effectively control the extent of starch gelatinization and protein denaturation, the moisture content of pulses should be tempered to levels below $41 \%$ prior to infrared heating (Liu S. et al., 2020). Arntfield et al. (2001) tempered the moisture content in lentils to $33 \%$ followed by infrared heating to internal temperatures of 138 and $170^{\circ} \mathrm{C}$. At $170^{\circ} \mathrm{C}$, micronized lentils had a darker colour and harder texture which could be unappealing to consumers. Relative to raw lentils, micronized lentils had a higher percentage of gelatinized starch and pectic materials with a decline in protein solubility, neutral detergent fibre, and phytic acid. Fasina et al. (2001) reduced the content of oligosaccharides and trypsin inhibitor in kidney beans, green peas, black beans, lentils, and pinto beans, without altering the protein and starch content using infrared heating at $140^{\circ} \mathrm{C}$. The amount of gelatinized starch resulting from infrared heating was $<10 \%$ due to the low moisture content $(<10 \%)$ in the seeds. Infrared heating significantly increases the solubility of pectin from pulses in water (Ndungu et al., 2012; Ogundele and Emmambux, 2018). This could be due to the structural changes in cell wall materials and degradation of pectin polymers in pulses which also contributed to the reduction in cooking time (Ogundele and Emmambux, 2018).

\section{CLINICAL AND ENVIRONMENTAL SIGNIFICANCE OF PULSE CONSUMPTION}

In this section, the health benefits derived from the consumption of pulses as shown in clinical trials are discussed. Additionally, the estimated environmental benefits of pulse consumption are also presented. Figure 1 shows the benefits of pulse consumption. In Western society, older adults have increased incidence of poor lipid profiles, are highly susceptible to cardiovascular diseases, and would benefit from carefully crafted diets. Abeysekara et al. (2012) demonstrated in a clinical trial that feeding older adults ( $\geq 50$ years) with pulse-based diets such as snacks, salads, soups, and meals prepared using beans, chickpeas, lentils, and peas reduced the risk factors such as total cholesterol by $8.3 \%$ and low density lipoprotein (LDL)-cholesterol by $7.9 \%$ compared to regular diets of participants. A reduction of total cholesterol 


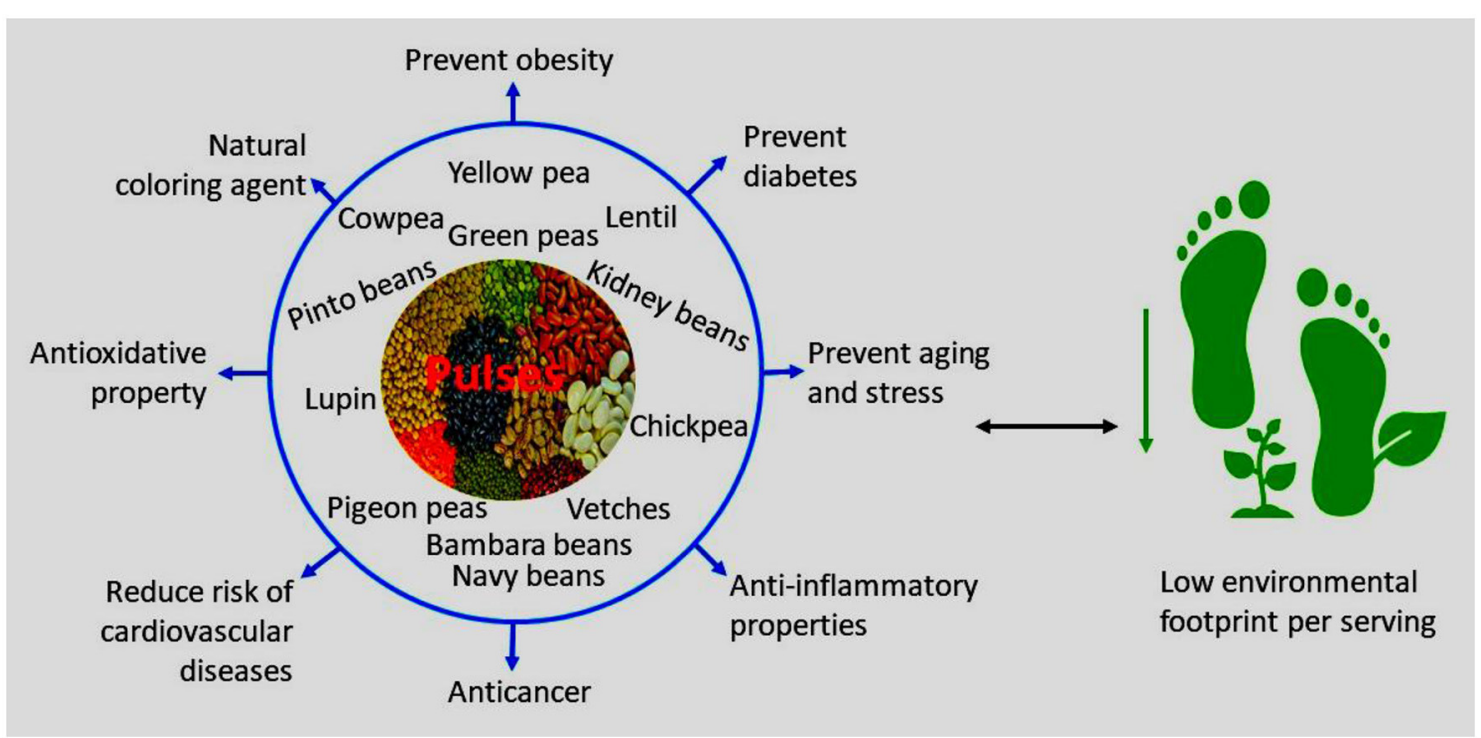

FIGURE 1 | Benefits of pulse consumption on health and the environment.

by $8.3 \%$ contributes to a decline in the risk of cardiovascular heart disease by about $17-25 \%$. A similar pattern was observed in obese individuals with an average age of about 36 years who were served with lentils, chickpeas, peas, and faba beans related meals (Crujeiras et al., 2007). Cooked lentils, chickpeas, peas, and beans are rich in $\mathrm{Mg}$, phenolic compounds (phenolic acids, flavonoids, and anthocyanins), proteins, and dietary fibre and have been proven in clinical trials to have the potential to reduce inflammatory markers and cardiovascular risk factors such as hyperglycemia, dyslipidemia, and insulin resistance (Hosseinpour-Niazi et al., 2015).

Alizadeh et al. (2014) tested the effects of a hypocaloric diet enriched in cooked pulses (white, red and wax beans, chickpeas, cowpea, lentils, and split peas) in premenopausal women with central obesity. The results showed beneficial effects of cooked pulses on systolic blood pressure, metabolic features, and hepatic function. Furthermore, consumption of diets rich in dietary fibres from pulse-based foods has a positive effect on the diversity and metabolic activity of the human microbiota to improve intestinal health. This was demonstrated through the consumption of diets supplemented with chickpea or its main oligosaccharide, raffinose, by healthy adults in a randomised crossover intervention study (Fernando et al., 2010). Fermented dietary fibres also serve as precursors for the production of luminal butyrate which has anti-inflammatory and antineoplastic properties and could be essential in the prevention of cancer (Hartman et al., 2010).

Ha et al. (2014) carried out a systematic review and metaanalysis of randomised controlled trials to elucidate the impact of dietary pulse consumption on established therapeutic lipid targets, namely, low-density lipoprotein (LDL) cholesterol, non-high-density lipoprotein (non-HDL) cholesterol and apolipoprotein B, to reduce the risk of cardiovascular diseases.
Notably, there was no significant effect of pulse consumption on non-high-density lipoprotein (non-HDL) cholesterol and apolipoprotein B. It was deduced that consuming $130 \mathrm{~g} / \mathrm{d}$ $(\sim 1$ serving per day) of pulses could reduce the level of LDL cholesterol by about $5 \%$ from the baseline.

Aside from the fact that pulses provide a promising alternative of formulating energy and nutrient rich diets necessary for the prevention of malnutrition and diet-related non-communicable diseases, pulses also contribute positively to environmental sustainability. For instance, Saget et al. (2020) performed a life cycle assessment, from cradle to fork, based on 16 impact categories for pasta oven cooked by using flours from either durum wheat or chickpea mixed with water. It was observed that there was a reduction in environmental footprint per servings for chickpea-based pasta in at least 10 of the impact categories investigated relative to the use of a cereal durum wheat. Also, when the evaluation was done on a nutritional density basis, chickpea demonstrated superior environmental benefits in 15 of the impact categories investigated. It must also be noted that cereal grains, which are usually used for the preparation of commonly eaten processed foods such as pasta, bread, and other bakery products, have a low content of essential amino acids lysine and threonine. The nutritional quality of bakery products produced from cereal grains could be improved by supplementing the formulation with pulses (Wood, 2009). To further enhance modern day agri-food systems to ensure environmental sustainability and nutritional security, studies investigating the processing of pulses for partial replacement of meats are emerging as shown in Table 2. Notably, aside from their nutritional attributes, the introduction of pulses into meat-based products at optimum ratios could improve the functionality (such as water holding capacity, gelation, emulsification, texture, and gelation) of mixed ingredients 
TABLE 2 | Processing of pulses to formulate sustainable pulse-based meat products.

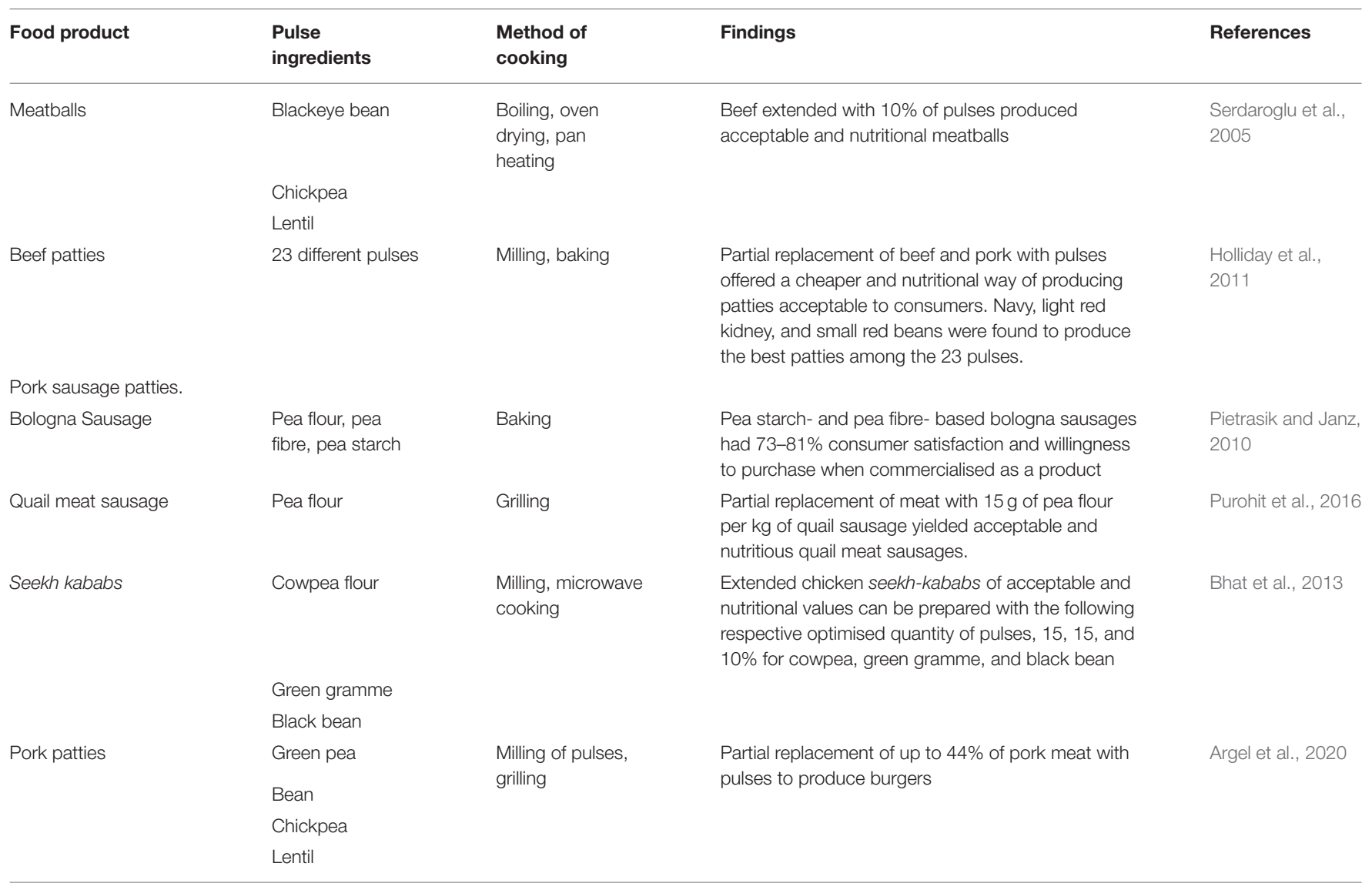

(Purohit et al., 2016). A reduction in the percentage of meat components in food products results in a decrease in greenhouse gas emissions. Another versatile benefit of most pulses in food processing is their potential use as a natural colouring agent due to the existence of pigments (such as chlorophyllunripe pea seeds; carotenoids-red lentils; and lutein and $\beta$-carotene-grass pea seeds) in the seed coats and cotyledons (Teterycz et al., 2020).

\section{FUTURE PERSPECTIVE AND CONCLUSION}

Food and nutritional security are fundamental to the wellbeing of any individual. A current challenge facing the world today is changing our diet to a healthier and environmentally sustainable dietary pattern. Pulses have enormous nutritional and health benefits in preventing malnutrition and chronic diseases while contributing positively to reducing environmental footprint. The health benefits of pulses have been linked to the existence of their bioactive molecules such as proteins, dietary fibres, and polyphenols with either nutritional or non-nutritional properties. Under conditions such as elevated concentrations, non-performance of the metabolic system of consumers, and interactions of bioactive compounds with food constituents, some of these bioactives with health benefits may have ambivalent properties to act as beneficial or antinutritional compounds. These antinutritional compounds could have adverse implications including toxicity, reducing protein digestibility and nutrient bioavailability, triggering allergenic and/or allergic-like reactions (such as favism), and causing negative physiological effects (such as bloating of stomach and abdominal pains). However, the type and quantity of nutritional and antinutritional food bioactives depend on the type of raw pulse seed. The bioavailability of nutrients can be increased by treating pulses to reduce/eliminate the antinutritional compounds.

Major limitations to the consumption and commercialisation of pulses include the strong beany taste, incomplete proteins, long processing time, lack of standardised techniques, and potential adverse effects from some bioactive constituents. The advancement in technology has resulted in the use of techniques such as genetic breeding to enhance the variability of pulse crops having low antinutritional compounds and high yield which can be inherited. Despite the potential benefits of enhanced genetic breeding programs, the net effect of such outcomes could be detrimental, as the antinutritional compounds are primarily produced as secondary metabolites and are essential to the survival of the pulse grain in the field. Besides, the benefits of bioactives present in pulses could be simply made to outweigh their potential adverse effects as antinutritional compounds when 
pulses are adequately processed prior to consumption. Processing before consumption helps to derive maximum nutritional and health benefits from the pulse seeds.

The lack of standardisation available to assess the nature of most clinical studies conducted using pulses and the effectiveness of different processing techniques in reducing antinutritional compounds in pulses is a major bottleneck. This makes it difficult to compare outcomes from different studies. For instance, the type of processing method and conditions used to prepare the pulse or pulse product is non-existent in clinical studies in the extant literature. A clear disconnect between the processing and chemistry in the laboratory or industry and the nutritionrelated clinical studies in humans. Notably, the processing technologies have different molecular impacts on pulse nutrients and antinutritional compounds which would influence the outcome of the study.

Also, specific studies investigating the link between the nutritional quality of pulses with food and nutritional insecurity in malnourished regions/countries are lacking in the extant literature. This is necessary to help inform the formulation of good food guidelines tailored-for-purpose to achieve food and nutritional security. For instance, the quality and quantity of nutrients, such as proteins, varies with pulses and will inform the required quantity per serving for each specific pulse needed to achieve equivalent impacts. More studies are also needed on the life cycle assessment on pulse-based products to deepen understanding of their environmental footprint benefits per (i) serving of pulse-based diets, and (ii) unit of nutrition serving.

Proteins sourced from pulses are classified as being incomplete proteins as they do not contain sufficient quantities of all the essential amino acids required in humans relative to animal sources of proteins. However, animal sources of proteins are a less sustainable approach in modern agri-food approaches requiring large acres of land and the generation of methane gases. Complete proteins from pulse-based meals can be obtained by consuming pulses in a well-balanced diet with

\section{REFERENCES}

Abdalla Hussein, M. (2012). Anti-inflammatory effect of natural heterocycle glucoside vicine obtained from Vicia faba L. its aglucone (divicine) their effect on some oxidative stress biomarkers in Albino rats. Free Radic Antioxidants 2, 44-54. doi: 10.5530/ax.2012.2.2.8

Abdel-Aal, E.-S. M. (2016). Processing Pulses to Enhance Bioactive and Anti-Nutritional Attributes. Retrieved from: Available online at: https:// canadianfoodbusiness.com/2016/06/20/processing-pulses-to-enhancebioactive-and-anti-nutritional-attributes/ (accessed February 15, 2021).

Abdullah, M. M. H., Gyles, C. L., Marinangeli, C. P. F., Carlberg, J. G., and Jones, P. J. H. (2015a). Cost-of-illness analysis reveals potential healthcare savings with reductions in type 2 diabetes and cardiovascular disease following recommended intakes of dietary fiber in Canada. Front. Pharmacol. 6:167. doi: 10.3389/fphar.2015.0 0167

Abdullah, M. M. H., Gyles, C. L., Marinangeli, C. P. F., Carlberg, J. G., and Jones, P. J. H. (2015b). Dietary fibre intakes and reduction in functional constipation rates among Canadian adults: a cost-of-illness analysis. Food Nutr. Res. 59:28646. doi: 10.3402/fnr.v59.28646 other crops such as cereals. The beany taste of pulses can be minimised through simple processing techniques such as soaking, germination, and fermentation. The common process for most pulses involves soaking and cooking via boiling. Whiles this process is simple, it takes a longer time to complete before consumption which is contrary to the current habits of consumers (Szczebyło et al., 2020). On the other hand, processed pulses which are commercially available including canned pulses, pulse meat alternatives, pulse protein concentrates, pulse dietary fibres, pulse flours, and pulse snacks are convenient and easy to be incorporated into different diets according to the consumer's preference.

Overall, pulses by virtue of their nutritional, health, and environmental benefits are ideal crops essential in meeting the sustainable development goals. Diverse processing techniques exist to reduce the percentage of antinutritional factors found in pulses, increase the bioavailability of macro- and micronutrients, and increase the varieties of pulse-based products for consumers. The processing techniques can be tailored to purpose and pulse type to achieve desired results.

\section{AUTHOR CONTRIBUTIONS}

CA contributed to conceptualisation and design of research goals, writing of initial draft, and final compilation of manuscript. GO-B contributed to writing of initial draught. KP contributed to the design of research goals, discussion, and overall revision of manuscript. ST contributed to the conceptualisation and design of the research goals and outline, discussion, supervision, and overall revision of manuscript. All authors contributed to the article and approved the submitted version.

\section{FUNDING}

Open access publication fee funded by University of Ottawa.

Abeysekara, S., Chilibeck, P. D., Vatanparast, H., and Zello, G. A. (2012). A pulsebased diet is effective for reducing total and LDL-cholesterol in older adults. $\mathrm{Br}$. J. Nutr. 108, S103-S110. doi: 10.1017/S0007114512000748

Acquah, C., Tibbetts, S. M., Pan, S., and Udenigwe, C. (2020a). "Chapter 19 Nutritional quality and bioactive properties of proteins and peptides from microalgae," in Handbook of Microalgae-Based Processes and Products, eds E. Jacob-Lopes, M. M. Maroneze, M. I. Queiroz, and P. Zepka (Academic Press), 493-531. doi: 10.1016/B978-0-12-818536-0.00019-1

Acquah, C., Zhang, Y., Dubé, M. A., and Udenigwe, C. C. (2020b). Formation and characterization of protein-based films from yellow pea (Pisum sativum) protein isolate and concentrate for edible applications. Curr. Res. Food Sci. 2, 61-69. doi: 10.1016/j.crfs.2019.11.008

Adeleye, O. O., Awodiran, S. T., Ajayi, A. O., and Ogunmoyela, T. F. (2020). Influence of extrusion cooking on physicochemical properties and starch digestion kinetics of Sphenostylis stenocarpa, Cajanus cajan, and Vigna subterranean grains. PLoS ONE 15:e0242697. doi: 10.1371/journal.pone.0242697

Alemany, L., Barbera, R., Alegría, A., and Laparra, J. M. (2014). Plant sterols from foods in inflammation and risk of cardiovascular disease: a real threat? Food Chem. Toxicol. 69, 140-9. doi: 10.1016/j.fct.2014.03.038 
Alizadeh, M., Gharaaghaji, R., and Pourghassem Gargari, B. (2014). The effects of legumes on metabolic features, insulin resistance and hepatic function tests in women with central obesity: a randomized controlled trial. Int. J. Preventive Med. 5, 710-720.

Alonso, R., Orúe, E., and Marzo, F. (1998). Effects of extrusion and conventional processing methods on protein and antinutritional factor contents in pea seeds. Food Chem. 63, 505-512. doi: 10.1016/S0308-8146(98)00037-5

American Association of Cereal Chemists (AACCFC) (2001). The definition of dietary fiber: report of the dietary fiber definition committee to the board of directors of the american association of cereal chemists. Cereal Foods World $46,112-126$.

Argel, N. S., Ranalli, N., Califano, A. N., and Andrés, S. C. (2020). Influence of partial pork meat replacement by pulse flour on physicochemical and sensory characteristics of low-fat burgers. J. Sci. Food Agric. 100, 3932-3941. doi: $10.1002 /$ jsfa. 10436

Arntfield, S. D., Scanlon, M. G., Malcolmson, L. J., Watts, B. M., Cenkowski, S., Ryland, D., et al. (2001). Reduction in lentil cooking time using micronization: comparison of 2 micronization temperatures. J. Food Sci. 66, 500-505. doi: 10.1111/j.1365-2621.2001.tb16139.x

Asif, M., Rooney, L. W., Ali, R., and Riaz, M. N. (2013). Application and opportunities of pulses in food system: a review. Crit. Rev. Food Sci. Nutr. 53, 1168-1179. doi: 10.1080/10408398.2011.574804

Avilés-Gaxiola, S., Chuck-Hernández, C., and Serna Saldívar, S. O. (2018). Inactivation methods of trypsin inhibitor in legumes: a review. J. Food Sci. 83, 17-29. doi: 10.1111/1750-3841.13985

Bassett, M. J., Lee, R., Symanietz, T., and McClean, P. E. (2002). Inheritance of reverse margo seedcoat pattern and allelism between the genes J for seedcoat color and L for partly colored seedcoat pattern in common bean. J. Am. Soc. Horticultural Sci. 127, 56-61. doi: 10.21273/JASHS.127.1.56

Bawa, S. A., Ofori, E. K. S., and Osae, M. (2017). Species diversity and relative abundance of Callosobruchus (Coleoptera: Chrysomelidae) in stored cowpea in four major agricultural produce markets in the central region, Ghana. J. Stored Prod. Res. 72, 117-120. doi: 10.1016/j.jspr.2017.04.007

Baysal, T., and Demirdöven, A. (2007). Lipoxygenase in fruits and vegetables: a review. Enzyme Microb. Technol. 40, 491-496. doi: 10.1016/j.enzmictec.2006.11.025

Ben-Belhassen, B., and Rawal, V. (2021). A Global Perspective on Pulse Production. Retrieved from: https://pulsepod.globalpulses.com/pod-feed/post/ a-global-perspective-on-pulse-production (accessed January 29, 2021).

Bessada, S. M. F., Barreira, J. C. M., and Oliveira, M. B. P. P. (2019). Pulses and food security: dietary protein, digestibility, bioactive and functional properties. Trends Food Sci. Technol. 93, 53-68. doi: 10.1016/j.tifs.2019.08.022

Better Health Care (BHC) (2021). Fibre in Food. Retrieved from: https://www. betterhealth.vic.gov.au/ (accessed March 12, 2021).

Bhat, Z. F., Pathak, V., and Fayaz, H. (2013). Effect of refrigerated storage on the quality characteristics of microwave cooked chicken seekh kababs extended with different non-meat proteins. J. Food Sci. Technol. 50, 926-933. doi: 10.1007/s13197-011-0410-4

Blair, M. W., Porch, T., Cichy, K., Galeano, C. H., Lariguet, P., Pankhurst, C., et al. (2007). Induced mutants in common bean (Phaseolus vulgaris), and their potential use in nutrition quality breeding and gene discovery. Isr. J. Plant Sci. 55, 191-200. doi: 10.1560/IJPS. 55.2.191

Brummer, Y., Kaviani, M., and Tosh, S. M. (2015). Structural and functional characteristics of dietary fibre in beans, lentils, peas and chickpeas. Food Res. Int. 67, 117-125. doi: 10.1016/j.foodres.2014.11.009

Cardador-Martínez, A., Maya-Ocaña, K., Ortiz-Moreno, A., Herrera-Cabrera, B. E., Dávila-Ortiz, G., Múzquiz, M., et al. (2012). Effect of roasting and boiling on the content of vicine, convicine and L-3,4-dihydroxyphenylalanine in Vicia faba L. J. Food Qual. 35, 419-428. doi: 10.1111/jfq.12006

Champ, M. M.-J. (2002). Non-nutrient bioactive substances of pulses. Br. J. Nutr. 88, 307-319. doi: $10.1079 / \mathrm{BJN} 2002721$

Chandrasekaran, S., Ramanathan, S., and Basak, T. (2013). Microwave food processing-a review. Food Res. Int. 52, 243-261. doi: 10.1016/j.foodres.2013.02.033

Chinma, C. E., Abu, J. O., Asikwe, B. N., Sunday, T., and Adebo, O. A. (2021). Effect of germination on the physicochemical, nutritional, functional, thermal properties and in vitro digestibility of Bambara groundnut flours. LWT 140:110749. doi: 10.1016/j.lwt.2020.110749
Chizoba Ekezie, F. G., Sun, D. W., Han, Z., and Cheng, J. H. (2017). Microwaveassisted food processing technologies for enhancing product quality and process efficiency: a review of recent developments. Trends Food Sci. Technol. 67, 58-69. doi: 10.1016/j.tifs.2017.05.014

Coda, R., Melama, L., Rizzello, C. G., Curiel, J. A., Sibakov, J., Holopainen, U., et al. (2015). Effect of air classification and fermentation by Lactobacillus plantarum VTT E-133328 on faba bean (Vicia faba L.) flour nutritional properties. Int. J. Food Microbiol. 193, 34-42. doi: 10.1016/j.ijfoodmicro.2014.10.012

Crujeiras, A. B., Parra, D., Abete, I., and Martínez, J. A. (2007). A hypocaloric diet enriched in legumes specifically mitigates lipid peroxidation in obese subjects. Free Radic. Res. 41, 498-506. doi: 10.1080/10715760601131935

Cuadrado, C., Hajos, G., Burbano, C., Pedrosa, M. M., Ayet, G., Muzquiz, M., et al. (2002). Effect of natural fermentation on the lectin of lentils measured by immunological methods. Food Agric. Immunol. 14, 41-49. doi: 10.1080/09540100220137655

Dahl, W. J., Foster, L. M., and Tyler, R. T. (2012). Review of the health benefits of peas (Pisum sativum L.). Br. J. Nutr. 108(Suppl. 1), S3-10. doi: $10.1017 /$ S0007114512000852

Dalmoro, A., Naddeo, C., Caputo, S., Lamberti, G., Guadagno, L., d'Amore, M., et al. (2018). On the relevance of thermophysical characterization in the microwave treatment of legumes. Food Funct. 9, 1816-1828. doi: $10.1039 / \mathrm{C} 7 \mathrm{FO} 01488 \mathrm{~K}$

Elsadr, H. T., Wright, L. C., Peter Pauls, K., and Bett, K. E. (2011). Characterization of seed coat post harvest darkening in common bean (Phaseolus vulgaris L.). Theor. Appl. Genet. 123, 1467-1472. doi: 10.1007/s00122-011-1683-8

Erfatpour, M., and Pauls, K. P. (2020). A R2R3-MYB gene-based marker for the non-darkening seed coat trait in pinto and cranberry beans (Phaseolus vulgaris L.) derived from 'Wit-rood boontje.' Theor. Appl. Genet. 133, 1977-1994. doi: 10.1007/s00122-020-03571-7

Ertaş, N., and Türker, S. (2014). Bulgur processes increase nutrition value: possible role in in-vitro protein digestability, phytic acid, trypsin inhibitor activity and mineral bioavailability. J. Food Sci. Technol. 51, 1401-1405. doi: 10.1007/s13197-012-0638-7

Fabbri, A. D. T., Schacht, R. W., and Crosby, G. A. (2016). Evaluation of resistant starch content of cooked black beans, pinto beans, and chickpeas. NFS J. 3, 8-12. doi: 10.1016/j.nfs.2016.02.002

Fasina, O., Tyler, B., Pickard, M., Zheng, G.-H., and Wang, N. (2001). Effect of infrared heating on the properties of legume seeds*. Int. J. Food Sci. Technol. 36, 79-90. doi: 10.1046/j.1365-2621.2001.00420.x

Fernando, W. M. U., Hill, J. E., Zello, G. A., Tyler, R. T., Dahl, W. J., and Van Kessel, A. G. (2010). Diets supplemented with chickpea or its main oligosaccharide component raffinose modify faecal microbial composition in healthy adults. Beneficial Microb. 1, 197-207. doi: 10.3920/BM2009.0027

Ferreira, H., Vasconcelos, M., Gil, A. M., and Pinto, E. (2021). Benefits of pulse consumption on metabolism and health: a systematic review of randomized controlled trials. Crit. Rev. Food Sci. Nutr. 61, 85-96. doi: $10.1080 / 10408398.2020 .1716680$

Food and Agriculture Organisation (FAO) (2021a). Crops. Retrieved from: http://www.fao.org/faostat/en/\#data/QC (accessed March 8, 2021).

Food and Agriculture Organisation (FAO) (2021b). Food-Based Dietary Guidelines. Retrieved from: http://www.fao.org/nutrition/nutrition- education/fooddietary-guidelines/en/ (accessed March 10, 2021).

Galindo, F. G., Toledo, R. T., and Sjöholm, I. (2005). Tissue damage in heated carrot slices. comparing mild hot water blanching and infrared heating. J. Food Eng. 67, 381-385. doi: 10.1016/j.jfoodeng.2004.0 5.004

Gnasegaran, G., Agyei, D., Pan, S., Sarethy, I., Acquah, C., and Danquah, M. (2017). "Process development for bioactive peptide production," in Food Bioactives Extraction and Biotechnology Applications, ed M. Puri (Cham: Springer Nature), 91-110. doi: 10.1007/978-3-319-51639-4_4

Goyoaga, C., Burbano, C., Cuadrado, C., Varela, A., Guillamón, E., Pedrosa, M. M., et al. (2008). Content and distribution of vicine, convicine and 1-DOPA during germination and seedling growth of two Vicia faba L. varieties. Europ. Food Res. Technol. 227, 1537-1542. doi: 10.1007/s00217-008-0 876-0

Granito, M., Torres, A., Frias, J., Guerra, M., and Vidal-valverde, C. (2005). Influence of fermentation on the nutritional value of two 
varieties of Vigna sinensis. Europ. Food Res. Technol. 220, 176-181. doi: 10.1007/s00217-004-1011-5

Gupta, R. K., Gangoliya, S. S., and Singh, N. K. (2015). Reduction of phytic acid and enhancement of bioavailable micronutrients in food grains. J. Food Sci. Technol. 52, 676-684. doi: 10.1007/s13197-013-0978-y

Güzel, D., and Sayar, S. (2012). Effect of cooking methods on selected physicochemical and nutritional properties of barlotto bean, chickpea, faba bean, and white kidney bean. J. Food Sci. Technol. 49, 89-95. doi: 10.1007/s13197-011-0260-0

Ha, V., Sievenpiper, J. L., de Souza, R. J., Jayalath, V. H., Mirrahimi, A., Agarwal, A., et al. (2014). Effect of dietary pulse intake on established therapeutic lipid targets for cardiovascular risk reduction: a systematic review and meta-analysis of randomized controlled trials. CMAJ Canad. Med. Assoc. J. 186, E252-E262. doi: $10.1503 / \mathrm{cmaj} .131727$

Habtamu Fekadu, G., and Ratta, N. (2014). Antinutritional factors in plant foods: potential health benefits and adverse effects. Int. J. Nutr. Food Sci. 3, 284-289. doi: $10.11648 /$ j.ijnfs.20140304.18

Han, I. H., and Baik, B. K. (2006). Oligosaccharide content and composition of legumes and their reduction by soaking, cooking, ultrasound, and high hydrostatic pressure. Cereal Chem. 83, 428-433. doi: 10.1094/CC-83-0428

Hartman, T. J., Albert, P. S., Zhang, Z., Bagshaw, D., Kris-Etherton, P. M., Ulbrecht, J., et al. (2010). Consumption of a legume-enriched, lowglycemic index diet is associated with biomarkers of insulin resistance and inflammation among men at risk for colorectal cancer. J. Nutr. 140, 60-67. doi: $10.3945 /$ jn. 109.114249

Hefnawy, T. H. (2011). Effect of processing methods on nutritional composition and anti-nutritional factors in lentils (Lens culinaris). Ann. Agric. Sci. 56, 57-61. doi: 10.1016/j.aoas.2011.07.001

Hemalatha, S., Platel, K., and Srinivasan, K. (2007). Influence of germination and fermentation on bioaccessibility of zinc and iron from food grains. Eur. J. Clin. Nutr. 61, 342-348. doi: 10.1038/sj.ejcn.1602524

Hernandez-Aguirre, A. I., Téllez-Pérez, C., San Martín-Azócar, A., and CardadorMartínez, A. (2020). Effect of instant controlled pressure-drop (DIC), cooking and germination on non-nutritional factors of common vetch (Vicia sativa spp.). Molecules 25:151. doi: 10.3390/molecules25010151

Holliday, D. L., Sandlin, C., Schott, A., Malekian, F., and Finley, J. W. (2011). Characteristics of meat or sausage patties using pulses as extenders. J. Culinary Sci. Technol. 9, 158-176. doi: 10.1080/15428052.2011.594731

Hosseinpour-Niazi, S., Mirmiran, P., Fallah-Ghohroudi, A., and Azizi, F. (2015). Non-soya legume-based therapeutic lifestyle change diet reduces inflammatory status in diabetic patients: a randomised cross-over clinical trial. Br. J. Nutr. 114, 213-219. doi: 10.1017/S0007114515001725

Hummel, M., Talsma, E. F., Taleon, V., Londoño, L., Brychkova, G., Gallego, S., et al. (2020). Iron, zinc and phytic acid retention of biofortified, low phytic acid, and conventional bean varieties when preparing common household recipes. Nutrients 12:658. doi: 10.3390/nu12030658

Jeevitha, G. C., Hebbar, H. U., and Raghavarao, K. S. M. S. (2013). Electromagnetic radiation-based dry blanching of red bell peppers: a comparative study. J. Food Process Eng. 36, 663-674. doi: 10.1111/jfpe.12030

Jiang, Z., Pulkkinen, M., Wang, Y., Lampi, A.-M., Stoddard, F. L., Salovaara, H., et al. (2016). Faba bean flavour and technological property improvement by thermal pre-treatments. LWT - Food Sci. Technol. 68, 295-305. doi: 10.1016/j.lwt.2015.12.015

Kalogeropoulos, N., Chiou, A., Ioannou, M., Karathanos, V. T., Hassapidou, M., and Andrikopoulos, N. K. (2010). Nutritional evaluation and bioactive microconstituents (phytosterols, tocopherols, polyphenols, triterpenic acids) in cooked dry legumes usually consumed in the Mediterranean countries. Food Chem. 121, 682-690. doi: 10.1016/j.foodchem.2010.01.005

Karaś, M., Jakubczyk, A., Szymanowska, U., Złotek, U., and Zielińska, E. (2017). Digestion and bioavailability of bioactive phytochemicals. Int. J. Food Sci. Technol. 52, 291-305. doi: 10.1111/ijfs.13323

Khattab, R. Y., and Arntfield, S. D. (2009). Nutritional quality of legume seeds as affected by some physical treatments 2. antinutritional factors. LWT - Food Sci. Technol. 42, 1113-1118. doi: 10.1016/j.lwt.2009.02.004

Kimura, A., Takako, F., Meili, Z., Shiori, M., Maruyama, N., and Utsumi, S. (2008). Comparison of physicochemical properties of $7 \mathrm{~S}$ and $11 \mathrm{~S}$ globulins from pea, fava bean, cowpea, and French bean with those of soybean-french bean $7 \mathrm{~S}$ globulin exhibits excellent properties. J. Agric. Food Chem. 56, 10273-10279. doi: 10.1021/jf801721b

Krishnamurthy, K., Khurana, H. K., Soojin, J., Irudayaraj, J., and Demirci, A. (2008). Infrared heating in food processing: an overview. Comprehens. Rev. Food Sci. Food Safety 7, 2-13. doi: 10.1111/j.1541-4337.2007.00024.x

Kurek, J. (2019). "Introductory chapter: alkaloids - their importance in nature and for human life," in Alkaloids - Their Importance in Nature and Human Life, ed K. Joanna (London: IntechOpen), 1-8. doi: 10.5772/intechopen.85400

Lee, H. S., Gilliland, S. E., and Carter, S. (2001). Amylolytic cultures of lactobacillus acidophilus : potential probiotics to improve dietary starch utilization. J. Food Sci. 66, 338-344. doi: 10.1111/j.1365-2621.2001.tb11343.x

Lee, S., Kwon, H. K., Park, H., and Park, Y. (2018). Solid-state fermentation of germinated black bean (Rhynchosia nulubilis) using Lactobacillus pentosus SC65 and its immunostimulatory effect. Food Biosci. 26, 57-64. doi: 10.1016/j.fbio.2018.09.009

Leterme, P. (2002). Recommendations by health organizations for pulse consumption. Br. J. Nutr. 88, 239-242. doi: 10.1079/BJN2002712

Liu, S., Yin, H., Pickard, M., and Ai, Y. (2020). Influence of infrared heating on the functional properties of processed lentil flours: a study focusing on tempering period and seed size. Food Res. Int. 136:109568. doi: 10.1016/j.foodres.2020.109568

Liu, Y., Ragaee, S., Marcone, M. F., and Abdel-Aal, E.-S. M. (2020). Composition of phenolic acids and antioxidant properties of selected pulses cooked with different heating conditions. Foods 9:908. doi: 10.3390/foods9070908

Liu, Z., Luo, Y., Zhou, T. T., and Zhang, W. Z. (2013). Could plant lectins become promising anti-tumour drugs for causing autophagic cell death? Cell Prolif. 46, 509-515. doi: 10.1111/cpr.12054

López-Amorós, M. L., Hernández, T., and Estrella, I. (2006). Effect of germination on legume phenolic compounds and their antioxidant activity. J. Food Composit. Anal. 19, 277-283. doi: 10.1016/j.jfca.2004.06.012

Luo, S., and Koksel, F. (2020). Physical and technofunctional properties of yellow pea flour and bread crumb mixtures processed with low moisture extrusion cooking. J. Food Sci. 85, 2688-2698. doi: 10.1111/1750-3841.15385

Luo, Y.-W., and Xie, W.-H. (2013). Effect of different processing methods on certain antinutritional factors and protein digestibility in green and white faba bean (Vicia faba L.). CyTA - J. Food 11, 43-49. doi: 10.1080/19476337.2012.681705

Ma, Z., Boye, J. I., Azarnia, S., and Simpson, B. K. (2016). Volatile flavor profile of saskatchewan grown pulses as affected by different thermal processing treatments. Int. J. Food Properties 19, 2251-2271. doi: 10.1080/10942912.2015.1121494

Ma, Z., Boye, J. I., and $\mathrm{Hu}$, X. (2017). In vitro digestibility, protein composition and techno-functional properties of Saskatchewan grown yellow field peas (Pisum sativum L.) as affected by processing. Food Res. Int. 92, 64-78. doi: 10.1016/j.foodres.2016.12.012

Ma, Z., Boye, J. I., and Hu, X. (2018). Nutritional quality and techno-functional changes in raw, germinated and fermented yellow field pea (Pisum sativum L.) upon pasteurization. LWT 92, 147-154. doi: 10.1016/j.lwt.2018.02.018

Majili, Z. S., Nyaruhucha, C., Kulwa, K., Mutabazi, K., Rybak, C., and Sieber, S. (2020). Preferences and consumption of pigeon peas among rural households as determinants for developing diversified products for sustainable health. Sustainability. 6130, 6130-6145. doi: 10.3390/su12156130

Malcolmson, L., and Han, J. (2019). "Pulse processing and utilization of pulse ingredients in foods," in Health Benefits of Pulses, ed W. Dahl (Cham: Springer). doi: 10.1007/978-3-030-12763-3_9

Maleki, S., and Razavi, S. H. (2020). Pulses' germination and fermentation: two bioprocessing against hypertension by releasing ACE inhibitory peptides. Critic. Rev. Food Sci. Nutr. 60, 1-18. doi: 10.1080/10408398.2020.1789551

Marconi, E., Ruggeri, S., Cappelloni, M., Leonardi, D., and Carnovale, E. (2000). Physicochemical, nutritional, and microstructural characteristic of chickpeas (Cicer arietinum L.) and common beans (Phaseolus vulgaris L.) following microwave cooking. J. Agric. Food Chem. 48, 5986-5994. doi: 10.1021/jf000 8083

Margier, M., Georgé, S., Hafnaoui, N., Remond, D., Nowicki, M., Du Chaffaut, L., et al. (2018). Nutritional composition and bioactive content of legumes: characterization of pulses frequently consumed in france and effect of the cooking method. Nutrients 10:1668. doi: 10.3390/nu10111668 
Marinangeli, C. P. F., Curran, J., Barr, S. I., Slavin, J., Puri, S., Swaminathan, S., et al. (2017). Enhancing nutrition with pulses: defining a recommended serving size for adults. Nutr. Rev. 75, 990-1006. doi: 10.1093/nutrit/nux058

Martín-Cabrejas, M. A., Aguilera, Y., Pedrosa, M. M., Cuadrado, C., Hernández, T., Díaz, S., et al. (2009). The impact of dehydration process on antinutrients and protein digestibility of some legume flours. Food Chem. 114, 1063-1068. doi: 10.1016/j.foodchem.2008.10.070

Mba, C. (2013). Induced mutations unleash the potentials of plant genetic resources for food and agriculture. Agronomy 3, 200-231. doi: 10.3390/agronomy3010200

Mbithi, S., Van Camp, J., Rodriguez, R., and Huyghebaert, A. (2001). Effects of sprouting on nutrient and antinutrient composition of kidney beans (Phaseolus vulgaris var. Rose coco). Europ. Food Res. Technol. 212, 188-191. doi: $10.1007 /$ s002170000200

Merga, B., and Haji, J. (2019). Economic importance of chickpea: production, value, and world trade. Cogent Food Agric. 5:1615718. doi: $10.1080 / 23311932.2019 .1615718$

Mudryj, A. N., Yu, N., and Aukema, H. M. (2014). Nutritional and health benefits of pulses. Appl. Physiol. Nutr. Metab. 39, 1197-1204. doi: 10.1139/apnm-2013-0557

Muzquiz, M., Varela, A., Burbano, C., Cuadrado, C., Guillamón, E., and Pedrosa, M. M. (2012). Bioactive compounds in legumes: pronutritive and antinutritive actions. implications for nutrition and health. Phytochem. Rev. 11, 227-244. doi: 10.1007/s11101-012-9233-9

Ndungu, K. E., Emmambux, M. N., and Minnaar, A. (2012). Micronisation and hot air roasting of cowpeas as pretreatments to control the development of hard-tocook phenomenon. J. Sci. Food Agric. 92, 1194-1200. doi: 10.1002/jsfa.4683

Ngo, D. H., and Vo, T. S. (2019). An updated review on pharmaceutical properties of gamma-aminobutyric acid. Molecules 24:2678. doi: $10.3390 /$ molecules 24152678

Ogundele, O. M., and Emmambux, M. N. (2018). Effect of infrared heating of pre-soaked whole and dehulled bambara groundnut (Vigna subterranea) seeds on their cooking characteristics and microstructure. LWT 97, 581-587. doi: 10.1016/j.lwt.2018.07.059

Ogundele, O. M., and Kayitesi, E. (2019). Influence of infrared heating processing technology on the cooking characteristics and functionality of African legumes: a review. J. Food Sci. Technol. 56, 1669-1682. doi: 10.1007/s13197-019-03661-5

Okagu, O. D., Wang, B., Acquah, C., and Udenigwe, C. C. (2018). "Protein-based nanodelivery systems for food applications," in Encyclopedia of Food Chemistry, eds L. Melton, F. Shahidi, and P. Varelis (Amsterdam: Elsevier), 719-726. doi: 10.1016/B978-0-08-100596-5.21864-7

Parisi, G., Tulli, F., Fortina, R., Marino, R., Bani, P., Dalle Zotte, A., et al. (2020). Protein hunger of the feed sector: the alternatives offered by the plant world. Ital. J. Anim. Sci. 19, 1204-1225. doi: 10.1080/1828051X.2020. 1827993

Pietrasik, Z., and Janz, J. A. M. (2010). Utilization of pea flour, starch-rich and fiber-rich fractions in low fat bologna. Food Res. Int. 43, 602-608. doi: 10.1016/j.foodres.2009.07.017

Portman, D., Dolgow, C., Maharjan, P., Cork, S., Blanchard, C., Naiker, M., et al. (2020). Frost-affected lentil (Lens culinaris M.) compositional changes through extrusion: potential application for the food industry. Cereal Chem. 97, 818-826. doi: 10.1002/cche.10296

Purohit, A. S., Reed, C., and Mohan, A. (2016). Development and evaluation of quail breakfast sausage. LWT Food Sci. Technol. 69, 447-453. doi: 10.1016/j.lwt.2016.01.058

Pusztai, A., and Grant, G. (1998). Assessment of lectin inactivation by heat and digestion. Methods Mol. Med. 9, 505-514. doi: 10.1385/0-89603-396-1:505

Qi, M., Zhang, G., Ren, Z., He, Z., Peng, H., Zhang, D., et al. (2020). Impact of extrusion temperature on in vitro digestibility and pasting properties of pea flour. Plant. Foods Hum. Nutr. 76, 26-30. doi: 10.1007/s11130-020-00 869-1

Rahate, K. A., Madhumita, M., and Prabhakar, P. K. (2021). Nutritional composition, anti-nutritional factors, pretreatments-cum-processing impact and food formulation potential of faba bean (Vicia faba L.): a comprehensive review. LWT 138:110796. doi: 10.1016/j.lwt.2020.11 0796

Raina, A., Laskar, R. A., Tantray, Y. R., Khursheed, S., Wani, M. R., and Khan, S. (2020). Characterization of induced high yielding cowpea mutant lines using physiological, biochemical and molecular markers. Sci. Rep. 10:3687. doi: 10.1038/s41598-020-60601-6

Rastogi, N. K. (2012). Recent trends and developments in infrared heating in food processing. Crit. Rev. Food Sci. Nutr. 52, 737-760. doi: $10.1080 / 10408398.2010 .508138$

Rawal, V., and Navarro, D. K. (2019). The Global Economy of Pulses. Rome: Food and Agriculture Organization.

Rifna, E. J., Ratish Ramanan, K., and Mahendran, R. (2019). Emerging technology applications for improving seed germination. Trends Food Sci. Technol. 86, 95-108. doi: 10.1016/j.tifs.2019.02.029

Rizzello, C. G., Losito, I., Facchini, L., Katina, K., Palmisano, F., Gobbetti, M., et al. (2016). Degradation of vicine, convicine and their aglycones during fermentation of faba bean flour. Sci. Rep. 6:32454. doi: 10.1038/srep32452

Robinson, G. H. J., Balk, J., and Domoney, C. (2019). Improving pulse crops as a source of protein, starch and micronutrients. Nutr. Bull. 44, 202-215. doi: $10.1111 /$ nbu. 12399

Sackesen, C., Erman, B., Gimenez, G., Grishina, G., Yilmaz, O., Yavuz, S. T., et al. (2020). IgE and IgG4 binding to lentil epitopes in children with red and green lentil allergy. Pediatric Allergy Immunol. 31, 158-166. doi: 10.1111/pai.13136

Saget, S., Costa, M., Barilli, E., Wilton de Vasconcelos, M., Santos, C. S., Styles, D., et al. (2020). Substituting wheat with chickpea flour in pasta production delivers more nutrition at a lower environmental cost. Sustain. Product. Consumpt. 24, 26-38. doi: 10.1016/j.spc.2020.06.012

Saldanha do Carmo, C., Varela, P., Poudroux, C., Dessev, T., Myhrer, K., Rieder, A., et al. (2019). The impact of extrusion parameters on physicochemical, nutritional and sensorial properties of expanded snacks from pea and oat fractions. $L W T$ 112:108252. doi: 10.1016/j.lwt.2019.108252

Samtiya, M., Aluko, R. E., and Dhewa, T. (2020). Plant food anti-nutritional factors and their reduction strategies: an overview. Food Product. Process. Nutr. 2, 1-14. doi: 10.1186/s43014-020-0020-5

Sanchez-Monge, R., Lopez-Torrejón, G., Pascual, C. Y., Varela, J., MartinEsteban, M., and Salcedo, G. (2004). Vicilin and convicilin are potential major allergens from pea. Clin. Exp. Allergy 34, 1747-1753. doi: $10.1111 / j .1365-2222.2004 .02085 . x$

Saskatchewan. (2021). Soil Improvements With Legumes. Retrieved from: https:// www.saskatchewan.ca/business/agriculture-natural-resources-and-industry/ agribusiness-farmers-and-ranchers/crops-and-irrigation/soils-fertility-andnutrients/soil-improvements- with-legumes (accessed February 10, 2021).

Schwingshackl, L., Schwedhelm, C., Hoffmann, G., Lampousi, A.-M., Knüppel, S., Iqbal, K., et al. (2017). Food groups and risk of all-cause mortality: a systematic review and meta-analysis of prospective studies. Am. J. Clin. Nutr. 105, 1462-1473. doi: 10.3945/ajcn.117.153148

Serdaroglu, M., Yildiz-Turp, G., and Abrodímov, K. (2005). Quality of lowfat meatballs containing Legume flours as extenders. Meat Sci. 70, 99-105. doi: 10.1016/j.meatsci.2004.12.015

Setia, R., Dai, Z., Nickerson, M. T., Sopiwnyk, E., Malcolmson, L., and Ai, Y. (2019). Impacts of short-term germination on the chemical compositions, technological characteristics and nutritional quality of yellow pea and faba bean flours. Food Res. Int. 122, 263-272. doi: 10.1016/j.foodres.2019.04.021

Sharma, G. P., Verma, R. C., and Pathare, P. B. (2005). Thin-layer infrared radiation drying of onion slices. J. Food Eng. 67, 361-366. doi: 10.1016/j.jfoodeng.2004.05.002

Shi, L., Arntfield, S. D., and Nickerson, M. (2018). Changes in levels of phytic acid, lectins and oxalates during soaking and cooking of Canadian pulses. Food Res. Int. 107, 660-668. doi: 10.1016/j.foodres.2018.02.056

Shi, L., Mu, K., Arntfield, S. D., and Nickerson, M. T. (2017). Changes in levels of enzyme inhibitors during soaking and cooking for pulses available in Canada. J. Food Sci. Technol. 54, 1014-1022. doi: 10.1007/s13197-017-2519-6

Shriver, S. K., and Yang, W. W. (2011). Thermal and nonthermal methods for food allergen control. Food Eng. Rev. 3, 26-43. doi: 10.1007/s12393-011-9033-9

Siddhuraju, P., and Becker, K. (2005). Nutritional and antinutritional composition, in vitro amino acid availability, starch digestibility and predicted glycemic index of differentially processed mucuna beans (Mucuna pruriens var. utilis): an under-utilised legume. Food Chem. 91, 275-286. doi: 10.1016/j.foodchem.2004.02.044

Simsek, S., El, S. N., Kancabas Kilinc, A., and Karakaya, S. (2014). Vegetable and fermented vegetable juices containing germinated seeds and sprouts of lentil and cowpea. Food Chem. 156, 289-295. doi: 10.1016/j.foodchem.2014.01.095 
Singh, B., Bhat, T. K., and Singh, B. (2003). Potential therapeutic applications of some antinutritional plant secondary metabolites. J. Agric. Food Chem 51, 5579-5597. doi: 10.1021/jf021150r

Singh, B., Singh, J. P., Shevkani, K., Singh, N., and Kaur, A. (2017). Bioactive constituents in pulses and their health benefits. J. Food Sci. Technol. 54, 858-870. doi: 10.1007/s13197-016-2391-9

Singh, S., Gamlath, S., and Wakeling, L. (2007). Nutritional aspects of food extrusion: a review. Int. J. Food Sci. Technol. 42, 916-929. doi: 10.1111/j.1365-2621.2006.01309.x

Sodedji, F. A. K., Agbahoungba, S., Nguetta, S.-P. A., Agoyi, E. E., Ayenan, M. A. T., Sossou, S. H., et al. (2020). Resistance to legume pod borer (Maruca vitrata Fabricius) in cowpea: genetic advances, challenges, and future prospects. J. Crop Improvement 34, 238-267. doi: 10.1080/15427528.2019.1680471

Stephen, A. M., Champ, M. M.-J., Cloran, S. J., Fleith, M., van Lieshout, L., Mejborn, H., et al. (2017). Dietary fibre in Europe: current state of knowledge on definitions, sources, recommendations, intakes and relationships to health. Nutr. Res. Rev. 30, 149-190. doi: 10.1017/S095442241700004X

Sun, X., Acquah, C., Aluko, R. E., and Udenigwe, C. C. (2020). Considering food matrix and gastrointestinal effects in enhancing bioactive peptide absorption and bioavailability. J. Funct. Foods 64:103680. doi: 10.1016/j.jff.2019.103680

Szczebyło, A., Rejman, K., Halicka, E., and Laskowski, W. (2020). Towards more sustainable diets-attitudes, opportunities and barriers to fostering pulse consumption in polish cities. Nutrients 12:1589. doi: 10.3390/nu12061589

Takács, K., Guillamon, E., Pedrosa, M. M., Cuadrado, C., Burbano, C., Muzquiz, M., et al. (2014). Study of the effect of instant controlled pressure drop (DIC) treatment on IgE-reactive legume-protein patterns by electrophoresis and immunoblot. Food Agric. Immunol. 25, 173-185. doi: 10.1080/09540105.2012.759539

Tassoni, A., Tedeschi, T., Zurlini, C., Cigognini, I. M., Petrusan, J.-I., Rodríguez, Ó., et al. (2020). State-of-the-Art production chains for peas, beans and chickpeas-valorization of agro-industrial residues and applications of derived extracts. Molecules 25:1383. doi: 10.3390/molecules 25061383

Teterycz, D., Sobota, A., Zarzycki, P., and Latoch, A. (2020). Legume flour as a natural colouring component in pasta production. J. Food Sci. Technol. 57, 301-309. doi: 10.1007/s13197-019-04061-5

Tilman, D., and Clark, M. (2014). Global diets link environmental sustainability and human health. Nature 515, 518-522. doi: 10.1038/nature13959

Tosh, S., Farnworth, E., Brummer, Y., Duncan, A., Wright, A., Boye, J., et al. (2013). Nutritional profile and carbohydrate characterization of spray-dried lentil, pea and chickpea ingredients. Foods 2, 338-349. doi: 10.3390/foods2030338

Tosh, S. M., and Yada, S. (2010). Dietary fibres in pulse seeds and fractions: characterization, functional attributes, and applications. Food Res. Int. 43:450-460. doi: 10.1016/j.foodres.2009.09.005

Tukker, A., Goldbohm, R. A., de Koning, A., Verheijden, M., Kleijn, R., Wolf, O., et al. (2011). Environmental impacts of changes to healthier diets in Europe. Ecol. Econ. 70, 1776-1788. doi: 10.1016/j.ecolecon.2011.05.001

Udenigwe, C. C., and Aluko, R. E. (2012). Food protein-derived bioactive peptides: production, processing, and potential health benefits. J. Food Sci. 77, R11-R24. doi: 10.1111/j.1750-3841.2011.02455.x

United Nations (UN) (2015). Transforming Our World: The 2030 Agenda for Sustainable Development. Retrieved from: Available online at: https://sdgs.un. org/2030agenda (accessed February 9, 2020).

United Nations (UN) (2021). Population. Retrieved from: Available online at: https://www.un.org/en/sections/issues/depth/population/ (accessed February 12, 2021).

Vadivambal, R., and Jayas, D. S. (2010). Non-uniform temperature distribution during microwave heating of food materials-a review. Food Bioprocess Technol. 3, 161-171. doi: 10.1007/s11947-008-0136-0
Veenstra, J. M., Duncan, A. M., Cryne, C. N., Deschambault, B. R., Boye, J. I., Benali, M., et al. (2010). Effect of pulse consumption on perceived flatulence and gastrointestinal function in healthy males. Food Res. Int. 43, 553-559. doi: 10.1016/j.foodres.2009.07.029

Wani, S. A., and Kumar, P. (2016). Influence of different mixtures of ingredients on the physicochemical, nutritional and pasting properties of extruded snacks. J. Food Measure. Character. 10, 690-700. doi: 10.1007/s11694-016-9353-9

Willett, W., Rockström, J., Loken, B., Springmann, M., Lang, T., Vermeulen, S., et al. (2019). Food in the anthropocene: the EAT-Lancet Commission on healthy diets from sustainable food systems. Lancet. 393, 447-492. doi: 10.1016/S0140-6736(19)31101-8

Wood, J. A. (2009). Texture, processing and organoleptic properties of chickpeafortified spaghetti with insights to the underlying mechanisms of traditional durum pasta quality. J. Cereal Sci. 49, 128-133. doi: 10.1016/j.jcs.2008. 07.016

World Health Organisation (WHO) (2020). Malnutrition. Retrieved from: Available online at: https://www-who-int.proxy.bib.uottawa.ca/news-room/ fact-sheets/detail/malnutrition (accessed February 8, 2021).

Wu, Z., Song, L., Feng, S., Liu, Y., He, G., Yioe, Y., et al. (2012). Germination dramatically increases isoflavonoid content and diversity in chickpea (Cicer arietinum L.) seeds. J. Agric. Food Chem. 60,8606-8615. doi: 10.1021/ jf3021514

$\mathrm{Xu}$, B., and Chang, S. K. C. (2008). Effect of soaking, boiling, and steaming on total phenolic contentand antioxidant activities of cool season food legumes. Food Chem. 110, 1-13. doi: 10.1016/j.foodchem.2008. 01.045

Xu, M., Jin, Z., Ohm, J.-B., Schwarz, P., Rao, J., and Chen, B. (2018). Improvement of the antioxidative activity of soluble phenolic compounds in chickpea by germination. J. Agric. Food Chem. 66, 6179-6187. doi: 10.1021/acs.jafc.8b02208

Xu, M., Jin, Z., Simsek, S., Hall, C., Rao, J., and Chen, B. (2019). Effect of germination on the chemical composition, thermal, pasting, and moisture sorption properties of flours from chickpea, lentil, and yellow pea. Food Chem. 295, 579-587. doi: 10.1016/j.foodchem.2019.05.167

$\mathrm{Xu}, \mathrm{M}$., Rao, J., and Chen, B. (2020). Phenolic compounds in germinated cereal and pulse seeds: classification, transformation, and metabolic process. Crit. Rev. Food Sci. Nutr. 60, 740-759. doi: 10.1080/10408398.2018.1550051

Yeo, J., and Shahidi, F. (2017). Effect of hydrothermal processing on changes of insoluble-bound phenolics of lentils. J. Funct. Foods 38, 716-722. doi: 10.1016/j.jff.2016.12.010

Yin, S. W., Tang, C. H., Wen, Q. B., and Yang, X. Q. (2011). Conformational and thermal properties of phaseolin, the major storage protein of red kidney bean (Phaseolus vulgaris L.). J. Sci. Food Agric. 91, 94-99. doi: 10.1002/jsfa.4155

Zheng, Y., Li, Y., Satija, A., Pan, A., Sotos-Prieto, M., Rimm, E., et al. (2019). Association of changes in red meat consumption with total and cause specific mortality among US women and men: two prospective cohort studies. BMJ 365:12110. doi: 10.1136/bmj.12110

Conflict of Interest: The authors declare that the research was conducted in the absence of any commercial or financial relationships that could be construed as a potential conflict of interest.

Copyright (c) 2021 Acquah, Ohemeng-Boahen, Power and Tosh. This is an openaccess article distributed under the terms of the Creative Commons Attribution License (CC BY). The use, distribution or reproduction in other forums is permitted, provided the original author(s) and the copyright owner(s) are credited and that the original publication in this journal is cited, in accordance with accepted academic practice. No use, distribution or reproduction is permitted which does not comply with these terms. 